\title{
Stakeholder perspectives on general competences: The case of graduates of Vietnam National University, Hanoi
}

\author{
Lan Thi Quynh Mai*
}

doi: http://dx.doi.org/10.18543/tjhe-7(2)-2020pp91-139

Received: 26 June 2019

Accepted: 13 March 2020

\begin{abstract}
This research draws from theories of graduate employability and transferable skills and the TASE project's 13 graduate competences model, to explore the evaluation of the various stakeholders concerning the degree to which VNU graduates have acquired general competences. The survey measured three variables: (i) importance, (ii) achievement and (iii) priority, using the four categories of 'none', 'weak', 'considerable', and 'strong'. Between February and December 2018, a total of 818 informants agreed to participate, including 168 employers, 152 alumni, 189 students who had just graduated in 2018 or were about to graduate, 51 lecturers and university managers, and 258 students. The importance of the 13 general competences was rated more highly than graduate achievement. The ability to uphold professional, moral and ethical values was rated by VNU employers as of greatest importance and the highest achievement. Similarly, VNU students and alumni rated this ability as their highest achievement. The ability to conduct research and the ability to understand, value, and respect diversity and multiculturalism were rated as of lowest importance by VNU employers. The former (ability to conduct research) was rated as of lowest importance by VNU alumni and their lowest achievement by both VNU alumni and VNU students. VNU students rated the latter ability (to understand, value, and respect diversity and multiculturalism) as of least importance. The ability to initiate, plan,
\end{abstract}

* Lan Thi Quynh Mai (lanmtq@vnu.edu.vn), PhD in Sociology from the University of Queensland (Australia), works at the Institute for Education Quality Assurance, Vietnam National University, Hanoi, as the Head of the Department for Quality Assurance Research and Management.

More information about the author is available at the end of this article.

Acknowledgements: In a sense, this work is the outcome of research begun at Vietnam National University, Hanoi (VNU), funded under research project number QG 18.58. The author gratefully acknowledges the enormous support of VNU Hanoi colleagues. Sincere thanks to the participants, who were generous in contributing their time and effort to the interviews. Analysis for this work was carried out at Deusto International Tuning Academy (DITA) at the University of Deusto, Bilbao, Spain, and was financially supported by a Tuning Short-Term Visit Scholarship (http://tuningacademy .org/short-term-visits-call/). 
organise, implement and evaluate courses of action was rated the lowest achievement by VNU employers. The ability to apply knowledge in practice was considered of greatest importance by both VNU students and alumni, but for the latter group this ability ranked equally with the ability to communicate clearly and effectively. Students gave most of their own general competences a significantly lower rating than that given by employers to alumni achievement.

Keywords: General competences; graduate employability; transferable skills; Tuning methodology; Vietnam National University Hanoi; stakeholders ratings.

\section{Introduction}

In the context of social change, the transition from the university to the workplace has become increasingly challenging for graduates. Because new types of jobs are being created, employers find that formal learning does not keep pace with changing workforce needs. Consequently, they are not looking for employees who will be a perfect fit, nor do they expect higher education to produce graduates who can meet all work requirements. Instead, they look for the ability to learn ${ }^{1}$ and attributes which enable graduates to adapt to the workplace, be flexible in moving between different jobs, and advance university-level disciplinary knowledge. ${ }^{2}$ These general competences are often independent of graduates' degree subjects. ${ }^{3}$ Surveys show that companies look for a graduate's ability to work in a team and relate with co-workers, clients, and collaborators - skills that, in many cases, prove to be more important than their technical knowledge. ${ }^{4}$

Crosling and Ward assert that teamwork skills are required by all employers, regardless of economic sector, specifically skill in building relationships, and the kind of communication most used in teamwork. ${ }^{5}$ Yorke and Harvey agree that these desirable competences are often independent of the degree subject and consist of interactive attributes, such as communication skills, interpersonal skills and team working; and personal attributes, such as

${ }^{1}$ Rupert Maclean and Victor Ordonez, "Work, skills development for employability and education for sustainable development," Educational Research for Policy and Practice 6, no. 2 (2007): 123-140.

2 Mantz Yorke and Lee Harvey, "Graduate Attributes and Their Development," New Directions for Institutional Research 2005, no. 128 (2005): 41-58, https://doi.org/10.1002/ir.162.

3 Yorke and Harvey, "Graduate attributes," 43.

4 Julio Hernández-March, Mónica Martín D. Peso, and Santiago Leguey, "Graduates' Skills and Higher Education: The Employers' Perspective," Tertiary Education and Management 15, no. 1 (2009): 10.

${ }^{5}$ Glenda Crosling and Ian Ward, "Oral Communication: The Workplace Needs and Uses of Business Graduate Employees,” English for Specific Purposes 21, no. 1 (2002): 41. 
sound intellect and problem solving, analytic, critical and reflective ability, willingness to learn and continue learning, flexibility and adaptability, risktaking and self-management skills. ${ }^{6}$ Michael Eraut remarks that what is emphasised at university and what is emphasised by employers are not always the same thing. ${ }^{7}$ The concern is that universities cannot train graduates to meet the demands of a rapidly changing world. ${ }^{8}$

In Europe, research on higher education and graduate employment in Europe, ${ }^{9}$ led by the Universität Gesamthochschule Kassel in Germany, was conducted during 1998-2000 in nine countries in the European Union, Norway, Czech Republic, and Japan to assess graduate competences. The research team developed 36 competences out of the body of literature on the subject and generated a questionnaire for graduates to evaluate work requirements and their achievements at graduation. Over 40,000 graduates from institutions of higher education responded. The survey results indicated that graduates believed that requirements on the job demanded more of them than were afforded by the competences acquired before graduation. A comparison of the perceived individual job requirements and acquired competences shows that graduates considered themselves fully qualified or even overqualified in the following five competences:

- Field-specific theoretical knowledge

- Broad general knowledge

- Foreign language proficiency

- Learning abilities

- Manual skills

When rating perceived work requirements some four years after graduation, graduates seemed to feel deficiencies in most areas. The ones most strongly emphasised were the following: ${ }^{10}$

- Negotiating

- Planning, coordinating and organising

6 Yorke and Harvey, "Graduate attributes," 43.

7 Michael Eraut, "Transfer of Knowledge between Education and Workplace Settings," in Workplace Learning in Context, eds. Helen Rainbird, Alison Fuller, and Anne Munro (London: Routledge, 2004), 201.

8 Hernández-March, Peso, and Leguey, “Graduates' Skills and Higher Education,” 10.

${ }^{9}$ Harald Schomburg and Ulrich Teichler, Higher Education and Graduate Employment in Europe: Results from Graduate Surveys from Twelve Countries, vol. 15 (Springer Science \& Business Media, 2007), 93.

${ }^{10}$ Schomburg and Teichler, Higher Education, 99. 
- Computer skills

- Time management

- Taking responsibility, decision-making

- Working under pressure

- Leadership

- Applying rules and regulations

In particular, the research results showed that in the cognitive domains emphasised in their majors, graduates felt better prepared for their job than the job actually required of them. In contrast, graduates often noted deficiencies concerning the application of knowledge to job tasks. Similar results were found for socio-communicative skills, values and orientations relevant in the workplace. ${ }^{11}$

A similar effort to renew the system of higher education in Europe is the Tuning project, conducted by the University of Deusto (Spain) and the University of Groningen (Netherlands). The Tuning project construes the concept of competences as describing the capacity for a dynamic combination of attributes that permit a competent performance, or as part of the final product of an educational process. Competences and skills are understood to include knowing and understanding (theoretical knowledge of an academic field, the capacity to know and understand), knowing how to act (practical and operational application of knowledge to certain situations), knowing how to be (values as an integral element of the way of perceiving and living with others and in a social context).

In 2003, the Tuning project administered a large-scale survey in Europe and Latin America, consulting more than 5,000 graduates who had completed their university study during the preceding five years. Nearly a thousand organisations and almost another thousand academics were also surveyed on the importance of the competences and the level of graduates' achievement of them. The Tuning project's model of competences was tested in five degree courses organised according to the European credit transfer system. The survey was then extended to other universities in four regions. The Tuning project agreed on a list of 16 generic competences, considered global because of their coincidence in the four regions covered in the project, but perceived and organised according to factors that respond to regional logic. ${ }^{12}$

${ }^{11}$ Schomburg and Teichler, Higher Education, 99.

12 Pablo Beneitone and Edurne Bartolomé, "Global Generic Competences with local Ownership: A Comparative Study from the Perspective of Graduates in Four World Regions," Tuning Journal for Higher Education 1, no. 2 (May 2014): 306. 
In South East Asia, the Tuning project (TASE) supported universities in 10 ASEAN countries and the ASEAN University network (AUN) to identify generic and specific competences for building up competence-based learning programmes of medicine, education, and civil engineering. Participants from European universities and ASEAN universities agreed on 13 general competences for the region, coinciding with 16 global competences. The various stakeholders made their own choice of 13 general graduate competences. Since VNU is an active member of AUN, the researcher at the VNU Institute for Education Quality Assurance aims to measure the assessment of VNU stakeholders using Tuning project methodology, thus making it possible to benchmark VNU graduates' general competences against those used in the TASE project. This paper discusses the results of the surveys among graduates, employers, lecturers and current students at Vietnam National University, Hanoi.

\section{Vietnamese context}

Contemporary Vietnam provides an arena for exploring changes in the workforce in the country's transition from a centrally planned economy to a more market-oriented one. The education offered by universities does not provide graduates with the skills and knowledge required for economic growth. Mona Mourshed, Diana Farrell, and Dominic Barton argue that there is still a disconnect between what educational providers, on the one hand, and employers, on the other, perceive to be necessary skills for the workforce. ${ }^{13}$ Universities provide programmes and train in skills that do not adequately reflect the needs of the labour market. ${ }^{14}$ In 2008, the World Bank reported that employers most often sought soft skills, or attitudes, and generic skills. While universities focus on problem-solving skills, such as "decisionmaking, learning, and information processing", employers would also like them to focus on the development of "interpersonal skills", needed for

${ }_{13}$ Mona Mourshed, Diana Farrell, and Dominic Barton, Education to Employment: Designing a System that Works (McKinsey Center for Government, 2013), 18, accessed October 17, 2019, https://www .compromisorse.com/upload/estudios/000/222/Education-toEmployment_FINAL.pdf.

${ }^{14}$ Christian Bodewig and Reena Badiani-Magnusson, Skilling up Vietnam: Preparing the Workforce for a Modern Market Economy (World Bank, 2014), 18, https://openknowledge. worldbank.org/bitstream/handle/10986/18778/888950PUB0Box301so0829400June 172014. pdf? sequence $=1$. 
negotiation, coaching, and conflict management. ${ }^{15}$ These employer concerns seem consistent, even when there are structural changes and when the demand for labour fluctuates. ${ }^{16}$

Economic renewal (the Doi Moi policy) was introduced by the Vietnamese government in 1986 to allow the country to make the transition from a planned economy to a market-oriented one. The demand for a workforce trained to meet the requirements of those changes in society is placed upon the universities. Tran Quang Trung and F. W. Swierczek contend that Vietnamese employers, like employers elsewhere in the world, demand that graduate attributes match the needs of the contemporary workplace, such as "learning, communication, information processing, problem solving, and interpersonal skills." 17

A survey conducted by Nguyen Thi Thanh Hong of a sample of 400 education students demonstrates that the learning methods used by these students at university were frequently characterised by "notetaking, combined with reading textbooks and reference material", "learning by memorising the lecture notes given in class", and "learning according to what has been set out by the course outline and syllabus". ${ }^{18}$ There is increasing concern that the limited scope, content and approaches to learning that students encounter in such university courses are inadequate to meet the demands of both education and other professional practices. ${ }^{19}$

\section{Graduate competences}

Graduate competence is "the proven ability to use knowledge, skills and personal, social and/or methodological abilities, in work or study situations and in professional and personal development." ${ }^{20}$ Competence is a general

${ }^{15}$ Quang Trung Tran and Fredric William Swierczek, "Skills Development in Higher Education in Vietnam," Asia Pacific Business Review 15, no. 4 (2009): 581, https://doi. org/10.1080/13602380802364175.

${ }^{16}$ World Bank, Vietnam - Higher Education and Skills for Growth (Washington, DC: World Bank, 2008), 169, accessed October 17, 2019, http://siteresources.worldbank.org/ INTEASTASIAPACIFIC/Resources/Vietnam-HEandSkillsforGrowth.pdf.

17 Tran and Swierczek, "Skills development," 565-86.

18 Thi Thanh Hong Nguyen, "Factors Influencing the Self-Study Quality for Education Theory Subject of the Students at Universities of Education," Vietnamese Education Review 182, no. 2, (2008): 22-4.

19 Tran and Swierczek, "Skills development," 565-86.

${ }^{20}$ European Parliament and European Council, "Recommendation of the European Parliament and of the Council of 23 April 2008 on the Establishment of the European 
term, covering a wide range of abilities. ${ }^{21}$ The skills that allow graduates to acquire the necessary work competences, satisfy the requirements of the modern workplace, and apply abstract cognitive abilities, are transferable. These desirable attributes are often independent of the degree subject, and consist of interactive abilities, including communication skills, interpersonal skills and team work, as well as personal attributes, including intellect and problem solving, analytic, critical and reflective ability, willingness to learn and continue learning, flexibility and adaptability, risk-taking and selfmanagement. ${ }^{22}$

The European Credit Transfer and Accumulation System (ECTS) Guide 2015 defines competence as "the proven ability to use knowledge, skills and personal, social and/or methodological abilities, in work or study situations and in professional and personal development". "In the context of the European Qualifications Framework, competence is described in terms of responsibility and autonomy" (Recommendation 2008/C 111/01). ${ }^{23}$ An educational program's learning process aims to foster competences. Competences are developed in all course units and are assessed at different stages of a program. Some competences relate to a subject-area (are specific to a field of study), whereas others are generic (common to any degree course).$^{24}$

Reports in the literature suggest that employers' perceptions play a key role in the definition of the required skills for graduates. ${ }^{25}$ Companies require workers with flexible skills, trainability, persuasive skills and teamwork skills. ${ }^{26}$ Most employers are looking for graduates who are proactive and can use higher level skills, including analysis, critique, synthesis and multilayered communication, to facilitate innovative teamwork in catalysing the

Qualifications Framework for Lifelong Learning," Official Journal of the European Union 51, no. C 111 (2008): 5, http://eur-lex.europa.eu/legal-content/EN/TXT/ PDF/?uri=CELEX:32008 $\mathrm{H} 0506(01) \&$ from $=\mathrm{EN}$.

${ }^{21}$ Howard Davies, "Competence-Based Curricula in the Context of Bologna and EU Higher Education Policy,” Pharmacy 5, no. 2 (2017): 64-75, https://doi.org/10.3390/ pharmacy5020029.

${ }^{22}$ Yorke and Harvey, "Graduate Attributes," 43.

${ }^{23}$ European Parliament and European Council, "Recommendation," 5.

${ }^{24}$ ECTS Users' Guide (Luxembourg: Publications Office of the European Union, 2015), 22, http://ec.europa.eu/dgs/education_culture/repository/education/library/publications/2015/ ects-users-guide_en.pdf.

${ }^{25}$ Fátima Suleman, "Employability Skills of Higher Education Graduates: Little Consensus on a Much-Discussed Subject," Procedia-Social and Behavioral Sciences 228 (2016): 171, https://doi.org/10.1016/j.sbspro.2016.07.025.

${ }^{26}$ Maclean and Ordonez, "Work, Skills Development," 135. 
transformation of their organisation. ${ }^{27}$ These are generic graduate attributes which have been conceptualised as the skills, knowledge and abilities of university graduates, beyond disciplinary content knowledge, which are applicable in a range of contexts and are acquired as a result of completing any undergraduate degree. ${ }^{28}$ These desirable attributes are often independent of the degree subject but allow graduates to acquire necessary skills, satisfy the requirements of the new workplace, transfer abstract cognitive skills, work with others, lead, and solve problems.

Bennett, Dunne, and Carré posit that the skills individual graduates develop are both constrained and enabled by work circumstances, particularly influencing the way graduates use their knowledge, from directly applying specific skills to thinking strategically about the application of more abstract knowledge. ${ }^{29}$ Depending on the context of transfer, the process can be described as "near transfer", where certain attributes enable graduates to transfer knowledge and skills to contexts similar to educational contexts, or "far transfer", where other attributes infuse and enable all scholarly learning and knowledge, transcend disciplinary boundaries, and enable students to reshape and transform knowledge to meet new challenges in contexts far removed from the original university discipline. ${ }^{30}$

With transferable skills, the implication is that "skills developed within one situation (education) are also useful when transferred to another situation (employment)." ${ }^{\prime 31}$ Transferable skills, such as effective communication and teamwork, are not specific to the subject one is currently studying, but are much valued by employers. ${ }^{32}$ Bennett contends that transferable skills are needed in any job and enable people to participate in a flexible and adaptable

${ }^{27}$ Lee Harvey, Sue Moon, Vicki Geall, and Ray Bower, Graduates' Work: Organisational Change and Students' Attributes (Birmingham: Centre for Research into Quality, 1997), 43, https://doi.org/10.1177/095042229701100504.

${ }^{28}$ Simon Christopher Barrie, "Understanding What we Mean by the Generic Attributes of Graduates," Higher Education 51, no. 2 (2006): 217, https://doi.org/10.1007/s10734-0046384-7.

${ }^{29}$ Neville Bennett, Elisabeth Dunne, and Clive Carré, Skills Development in Higher Education and Employment (Florence: Taylor \& Francis, Inc., 2000): 16.

${ }^{30}$ Bennett, Dunne, and Carré, Skills Development, 17.

${ }^{31}$ Stephen Fallows and Christine Steven, "The Skills Agenda," in Integrating Key Skills in Higher Education: Employability, Transferable Skills and Learning for Life, eds. Stephen Fallows and Christine Steven (London: Kogan Page, 2000), 3-12.

${ }^{32}$ Martin J. Haigh and Marianne P. Kilmartin, "Student Perceptions of the Development of Personal Transferable Skills," Journal of Geography in Higher Education 23, no. 2 (1999): 196, https://doi.org/10.1080/03098269985461. 
workforce ${ }^{33}$ Her summary of transferable skills includes personal skills, such as the ability to work well with others, the ability to organise, selfmotivation,"a basic capability to use information technology", and also communication skills, initiative, creativity, the capacity to solve problems, and leadership. Bennett reasons that transferable skills are important because they permit a freshly appointed graduate to make an immediate contribution to a business, especially a smaller firm. ${ }^{34}$

Haigh and Kilmartin argue that transferable skills include a number of categories, such as 1 - problem solving (requiring analysis, lateral thinking, setting questions, identifying strategies, evaluating success); 2 communication (involving reading/listening, choice of styles, coherent argument, analysis, synthesis, self-evaluation, peer evaluation, author evaluation); 3 - learning skills (necessitating independence, cooperation, ranges of strategies); 4 - self-management (demanding the ability to clarify values, set goals, manage time, assess self); 5 - information skills (including literature research, information retrieval, information handling, referencing); and 6 - teamwork (taking responsibility, taking initiative, negotiation, team evaluation)..$^{35}$

Similarly, Fallows and Steven insist that transferable skills include the retrieval and handling of information, communication and presentation, planning and problem solving, social development and interaction. ${ }^{36}$ Moreover, Stephenson posits that capable people have confidence in their ability to take effective, appropriate action, explain what they are seeking to achieve, live and work effectively with others, and continue to learn from their experience, both as individuals and in association with others, in a diverse and changing society. ${ }^{37}$

In the same vein, Bennett maintains that the general list of transferable skills can be broadly understood to include qualities, characteristics, skills and knowledge that promote employability, both in general and specifically for graduates. ${ }^{38}$

${ }^{33}$ Roger Bennett, "Employers' demands for personal transferable skills in graduates: A content analysis of 1000 job advertisements and an associated empirical study," Journal of Vocational Education and training 54, no. 4 (2002): 457, https://doi. org/10.1080/13636820200200209.

${ }^{34}$ Bennett, "Employers' demands," 457-76.

${ }^{35}$ Haigh and Kilmartin, "Student perceptions," 196.

${ }^{36}$ Fallows and Steven, "The skills agenda," 8.

37 John Stephenson, "The Concept of Capability and Its Importance in Higher Education," in Capability and quality in higher education, eds. John Stephenson and Mantz Yorke (London: Kogan Page, 1998), 1-13.

${ }^{38}$ Bennett, "Employers' demands," 457-76. 
Barrie classifies graduate attributes according to a four-level framework, ordered by complexity. The two most complex conceptions of generic attributes (as learning outcomes) identified in his research including the "enabling" and "translation" conceptions. ${ }^{39} \mathrm{He}$ contends that three important learning outcomes of university education, such as scholarship, global citizenship and lifelong learning, are generic attributes analogous to the "enabling" conception. These include interwoven skills, abilities and attributes at the heart of disciplinary knowledge and human capability. Scholarship is an attitude or stance towards knowledge. Global citizenship is an attitude or stance towards the world, and lifelong learning is an attitude or stance of students towards themselves. The enabling of graduate attributes is supported by the development of these attributes in their translation (i.e., application). The translation level generic attributes enable graduates to make use of, or apply, disciplinary knowledge, thus potentially changing and transforming such knowledge through its application. Included on the translation level are clusters of linked personal attributes, cognitive abilities and skills in application, which are the learning outcomes that graduates possess, together with knowledge of a discipline. These skills and abilities are organised into the five key clusters: research and inquiries; information literacy; personal and intellectual autonomy; ethical, social and professional understanding; and communication..$^{40}$

These generic attributes are transferable, transcending disciplinary boundaries, even though they are initially developed within disciplinary contexts. They provide the building blocks for knowledge of a discipline but are more long-lasting and important than the disciplinary knowledge they support. Once developed, these graduate attributes are perceived to provide a reusable framework that enables students/graduates to acquire and shape new knowledge as required - even in the context of other disciplines. ${ }^{41}$

These general competences and transferable skills can be found in Haigh and Kilmartin's model of components of general competences, ${ }^{42}$ and the 13 general competences model of the TASE project. Haigh and Kilmartin's

${ }^{39}$ Simon Christopher Barrie, "Academics' understandings of generic graduate attributes: A conceptual basis for lifelong learning," in Graduate Attributes, Learning and Employability. Lifelong Learning, eds. Paul Hager and Susan Holland (Book Series, v. 6, Dordrecht: Springer, 2006), 157-8, https://doi.org/10.1007/1-4020-5342-8_8.

${ }^{40}$ Barrie, “Academics' Understandings," 158-59.

${ }^{41}$ Barrie, "Understanding," 229-30.

42 Barrie, "Understanding," 229-30. 
model consists of six groups of skills, such as problem solving, communication, learning skills, self-management, and teamwork. ${ }^{43}$ Meanwhile, the TASE model includes 13 general competences and abilities: to work collaboratively and effectively in diverse contexts; to use information and communication technology purposefully and responsibly; to uphold professional, moral and ethical values; to demonstrate responsibility and accountability towards society and the environment; to communicate clearly and effectively; to think critically, reflectively and innovatively; to understand, value, and respect diversity and multiculturalism; to pursue lifelong learning and continual professional development; to demonstrate problem solving abilities; to initiate, plan, organise, implement and evaluate courses of action; to conduct research; to demonstrate leadership attributes; and to apply knowledge in practice. ${ }^{44}$

This research draws from theories of graduate employability and transferable skills, and specifically from the TASE project's 13 graduate competences model,$^{45}$ to explore the evaluations of the various stakeholders of Vietnam National University, Hanoi, on the degree to which VNU graduates have acquired general competences and to benchmark these competences against the results of the TASE model.

\section{Research method}

This qualitative research uses survey questionnaires to measure stakeholder evaluations of 13 general competences according to three variables: (i) importance, (ii) achievement and (iii) priority. The four categories of 'none', 'weak', 'considerable', and 'strong' are used to form a Likert scale for measuring.

The survey questionnaires were administered among employers, alumni, new graduates in 2018, final-year students, lecturers, and current students of VNU. Research team members approached informants in person, at seminars and through email, to invite them to participate. The questionnaire included questions to obtain demographic information about the informants.

From February to December 2018, the survey was conducted among alumni recruiters, alumni, recent graduates in 2018, final-year students,

${ }^{43}$ Haigh and Kilmartin, "Student Perceptions," 198.

${ }^{44}$ Tuning Academy, "Tuning Asia - South East, Second Meeting Report” (Unpublished document, Tuning Academy, University of Deusto, 2017), http://tuningasia-southeast.org/ second-meeting/

${ }^{45}$ Tuning Education Structures in Europe, https://slideplayer.com/slide/1578662/. 
lecturers, and current students in years 1,2 , and 3 at VNU, yielding a total of 818 informants (200 men and 560 women; 58 surveys were discarded because of missing values).

Table 1

Informants

\begin{tabular}{|c|c|c|c|c|c|c|}
\hline & \multirow{2}{*}{$\begin{array}{c}\text { Total } \\
\text { informants }\end{array}$} & \multicolumn{2}{|c|}{ Sex } & \multirow{2}{*}{$\begin{array}{l}\text { Missing } \\
\text { value }\end{array}$} & \multirow{2}{*}{$\begin{array}{l}\text { Total } \\
\text { valid }\end{array}$} \\
\hline & & & Male & Female & & \\
\hline \multirow[t]{5}{*}{ Group } & Employers & 168 & 76 & 77 & 15 & 153 \\
\hline & Alumni & 152 & 30 & 121 & 1 & 151 \\
\hline & $\begin{array}{l}2018 \text { Graduates, \& } \\
\text { Final-year students }\end{array}$ & 189 & 37 & 144 & 8 & 181 \\
\hline & Lecturer, Dean, Rector & 51 & 32 & 19 & 0 & 51 \\
\hline & Current students & 258 & 25 & 199 & 34 & 224 \\
\hline \multicolumn{2}{|l|}{ Total } & 818 & 200 & 560 & 58 & 760 \\
\hline
\end{tabular}

\section{Employers}

The 168 employers who returned the questionnaires included 76 men $(45.2 \%)$ and 77 women $(45.8 \%) ; 15(8.9 \%)$ did not specify their gender. Their ages ranged from 22 to 64 years and their occupations included managers, directors and staff.

\section{Alumni}

The 158 alumni who completed the survey included 30 men, 121 women, and 7 who did not specify their gender. Of these, $46.7 \%$ ( 71 people) secured jobs right after graduation, and 30.3\% found a job 1-6 months after graduation; $67.1 \%$ (102 people) worked in junior positions and 8.6\% (13 people) in management positions.

New graduates in 2018 and final-year students (year 4 students who would graduate in 2019)

The numbers of new graduates in 2018 and final-year students (year 4 students who would graduate in 2019) were as follows: 
A total of 189 students who graduated in 2018 and final-year students (who would graduate in 2019) participated in the survey, 37 men (19.6\%), 144 women $(76.2 \%)$, and 8 who did not specify their gender. The questionnaires were distributed on graduation day or in class for finalyear students (year 4). Of these, 51.9\% (98 students) had found jobs already.

\section{Lecturers, deans, rector}

Forty lecturers, 9 deans, 1 vice-dean and 1 vice-rector responded to the questionnaires. Their ages ranged from 24 to 61 (32 men and 19 women).

\section{Current students}

Of current students, 258 answered the questionnaires; 25 men (9.7\%), 199 women $(77.1 \%)$ and $34(13.2 \%)$ who did not mention their gender. Most students were born between 1997 and 2000 (97\%). Nineteen were year 1 students (7.36\%), 97 year $2(37.6 \%), 64$ year $3(24.8 \%)$ and 27 year 4 $(10.5 \%) ; 51(19.8 \%)$ did not specify their year of study.

In addition to the survey questionnaire, the researcher also conducted semi-structured interviews with several employers, alumni and current students to gain an in-depth understanding of the mismatch between graduates' achievement of the 13 general competences and the requirements of the workplace. Ten alumni ( 7 women, 3 men), 5 employers ( 3 women, 2 men) who are also VNU alumni, and 6 current students ( 3 women, 3 men) agreed to participate. The interviews were recorded and analysed using the 13 general competences as the framework for analysis.

In the questionnaires for 51 lecturers, the deans, rector and 70/152 alumni (22 men, 48 women) there was an open-ended question asking them to describe activities or stages that indicated student achievement of the competences. Among 70 alumni, $40 \%$ (28 people) found jobs right after graduation, and $22.9 \%$ (16 people) secured jobs 1-6 months after graduation. These individuals graduated between 2000 and 2019, mostly between 2015 and 2017 (2017, 12 graduates; 2015, 9 graduates; 2016, 9 graduates).

Data analysis was carried out using SPSS software at the Deusto International Tuning Academy (DITA) at the University of Deusto, Bilbao, Spain, and was financially supported by a Tuning Short-Term Visit Scholarship (http://tuningacademy.org/short-term-visits-call/). 


\section{Findings}

V.1. Mean difference is significant, ANOVA analysis, Scheffe test

IV.1.1. Mean difference significant, ANOVA analysis, Scheffe test of the IMPORTANCE of general competences

Table 2

Multiple Comparisons of the Importance of GCs

Scheffe

\begin{tabular}{|c|c|c|c|c|c|c|c|}
\hline $\begin{array}{l}\text { Dependent } \\
\text { Variable }\end{array}$ & (I) Group & $\begin{array}{c}\text { Mean } \\
\text { (I) }\end{array}$ & (J) Group & $\begin{array}{c}\text { Mean } \\
(J)\end{array}$ & $\begin{array}{c}\text { Mean } \\
\text { Difference } \\
(\mathrm{I}-\mathrm{J})\end{array}$ & $\begin{array}{l}\text { Std. } \\
\text { Error }\end{array}$ & Sig. \\
\hline $\begin{array}{l}\text { GC1 - Ability } \\
\text { to work } \\
\text { collaboratively } \\
\text { and effectively } \\
\text { in diverse } \\
\text { contexts }\end{array}$ & $\begin{array}{l}2018 \\
\text { Graduates } \\
\text { and final } \\
\text { year } \\
\text { students }\end{array}$ & 3.42 & $\begin{array}{l}\text { Lecturer, } \\
\text { Dean, } \\
\text { Rector }\end{array}$ & 3.71 & $-.285^{*}$ & .091 & .047 \\
\hline $\begin{array}{l}\text { GC11 - Ability } \\
\text { to conduct } \\
\text { research }\end{array}$ & $\begin{array}{l}\text { Lecturer, } \\
\text { Dean, } \\
\text { Rector }\end{array}$ & 3.44 & Alumni & 3.07 & $.365^{*}$ & .108 & .023 \\
\hline \multirow{3}{*}{$\begin{array}{l}\text { GC12 - } \\
\text { Ability to } \\
\text { demonstrate } \\
\text { leadership } \\
\text { attributes }\end{array}$} & \multirow{3}{*}{$\begin{array}{l}\text { Lecturer, } \\
\text { Dean, } \\
\text { Rector }\end{array}$} & \multirow[t]{3}{*}{2.92} & Employer & 3.39 & $-.471^{*}$ & .104 & .000 \\
\hline & & & $\begin{array}{l}2018 \\
\text { Graduate } \\
\text { and } \\
\text { Final-year } \\
\text { students }\end{array}$ & 3.41 & $-.490^{*}$ & .103 & .000 \\
\hline & & & $\begin{array}{l}\text { Current } \\
\text { Student }\end{array}$ & 3.31 & $-.390^{*}$ & .099 & .004 \\
\hline
\end{tabular}

In ANOVA analysis, Scheffe test:

- For GC1 - the mean difference between the lecturer, dean, rector group and the 2018 graduates/final-year student group is significant at the 0.047 level. The highest mean value (3.71) is for the lecturer, dean, rector group; the lowest mean value (3.42) is for the graduates/ final-year student group. 
- For GC11 - the mean difference between the lecturer, dean, rector group and the alumni group is significant at the 0.023 level. The highest mean value (3.44) is for the lecturer, dean, rector group; the lowest mean value is (3.07) for the alumni group.

- For GC12 - the mean difference is significant between the lecturer, dean, rector group (1) and the three other groups; for example, between Group (1) and the employer group at the 0.000 level, between Group (1) and the 2018 graduates/final-year student group at the 0.000 level, and between Group (1) and current student group at the 0.004 level.

The highest mean value (3.41) is for the 2018 graduates/final-year student group, and the lowest mean value (2.92) is for the lecturer, dean, rector group.

IV .1.2. Mean difference, ANOVA analysis, and Scheffe test of achievement

Table 3

Multiple Comparisons of the Achievement of GCs Scheffe

\begin{tabular}{|l|l|l|l|l|l|l|l|}
\hline \multicolumn{1}{c}{$\begin{array}{c}\text { Dependent } \\
\text { Variable }\end{array}$} & (I) Group & $\begin{array}{c}\text { Mean } \\
(\mathrm{I})\end{array}$ & (J) Group & $\begin{array}{c}\text { Mean } \\
(\mathrm{J})\end{array}$ & $\begin{array}{c}\text { Mean } \\
\text { Difference } \\
(\mathrm{I}-\mathrm{J})\end{array}$ & $\begin{array}{c}\text { Std. } \\
\text { Error }\end{array}$ & Sig. \\
\hline $\begin{array}{l}\text { GC1 - Ability } \\
\text { to work } \\
\text { collaboratively } \\
\text { and effectively } \\
\text { in diverse } \\
\text { contexts }\end{array}$ & $\begin{array}{l}\text { Current } \\
\text { student }\end{array}$ & 2.80 & Employer & 3.06 & $-.263^{*}$ & .055 & .000 \\
\cline { 3 - 8 } & Alumni & 3.11 & $-.314^{*}$ & .056 & .000 \\
\hline $\begin{array}{l}\text { GC2 - Ability } \\
\text { to use } \\
\text { information } \\
\text { and } \\
\text { communication } \\
\text { technology } \\
\text { purposefully } \\
\text { and responsibly }\end{array}$ & $\begin{array}{l}\text { Current } \\
\text { student }\end{array}$ & 2.80 & Employer & 3.07 & $-.266^{*}$ & .058 & .000 \\
\cline { 3 - 8 } & & Alumni & 3.07 & $-.265^{*}$ & .059 & .001 \\
\hline
\end{tabular}




\begin{tabular}{|c|c|c|c|c|c|c|c|}
\hline $\begin{array}{l}\text { Dependent } \\
\text { Variable }\end{array}$ & (I) Group & $\begin{array}{l}\text { Mean } \\
\text { (I) }\end{array}$ & (J) Group & $\begin{array}{c}\text { Mean } \\
(J)\end{array}$ & $\begin{array}{c}\text { Mean } \\
\text { Difference } \\
(I-J)\end{array}$ & $\begin{array}{l}\text { Std. } \\
\text { Error }\end{array}$ & Sig. \\
\hline \multirow{4}{*}{$\begin{array}{l}\text { GC3 - Ability } \\
\text { to uphold } \\
\text { professional, } \\
\text { moral and } \\
\text { ethical values }\end{array}$} & \multirow{3}{*}{$\begin{array}{l}\text { Lecturer, } \\
\text { Dean, } \\
\text { Rector }\end{array}$} & \multirow[t]{3}{*}{2.96} & Employer & 3.27 & $-.308 *$ & .088 & .017 \\
\hline & & & Alumni & 3.42 & $-.455^{*}$ & .089 & .000 \\
\hline & & & $\begin{array}{l}\text { Current } \\
\text { Student }\end{array}$ & 3.27 & $-.305^{*}$ & .084 & .011 \\
\hline & $\begin{array}{l}\text { Graduates } \\
\text { in } 2018 \\
\text { and Final- } \\
\text { year }\end{array}$ & 3.22 & Alumni & 3.42 & $-.194 *$ & .061 & .039 \\
\hline \multirow{3}{*}{$\begin{array}{l}\text { GC5 - Ability to } \\
\text { communicate } \\
\text { clearly and } \\
\text { effectively }\end{array}$} & \multirow{3}{*}{$\begin{array}{l}\text { Current } \\
\text { student }\end{array}$} & \multirow[t]{3}{*}{2.73} & Employer & 2.99 & $-.255^{*}$ & .058 & .001 \\
\hline & & & Alumni & 3.15 & $-.414^{*}$ & .060 & .000 \\
\hline & & & $\begin{array}{l}2018 \\
\text { Graduates } \\
\text { and Final- } \\
\text { year }\end{array}$ & 3.01 & $-.279 *$ & .057 & .000 \\
\hline \multirow{3}{*}{$\begin{array}{l}\text { GC6 - Ability to } \\
\text { think critically, } \\
\text { reflectively and } \\
\text { innovatively }\end{array}$} & \multirow{3}{*}{$\begin{array}{l}\text { Current } \\
\text { student }\end{array}$} & \multirow[t]{3}{*}{2.57} & Employer & 2.88 & $-.304 *$ & .066 & .000 \\
\hline & & & Alumni & 3.00 & $-.429 *$ & .068 & .000 \\
\hline & & & $\begin{array}{l}2018 \\
\text { Graduates } \\
\text { and Final- } \\
\text { year }\end{array}$ & 2.85 & $-.282^{*}$ & .064 & .001 \\
\hline \multirow{2}{*}{$\begin{array}{l}\text { GC8 - Ability } \\
\text { to carry out } \\
\text { lifelong } \\
\text { learning and } \\
\text { continual } \\
\text { professional } \\
\text { development }\end{array}$} & \multirow{2}{*}{$\begin{array}{l}\text { Current } \\
\text { student }\end{array}$} & \multirow[t]{2}{*}{2.77} & Employer & 3.10 & $-.327 *$ & .063 & .000 \\
\hline & & & Alumni & 3.07 & $-.294^{*}$ & .064 & .000 \\
\hline \multirow{3}{*}{$\begin{array}{l}\text { GC9 - } \\
\text { Demonstrate } \\
\text { problem- } \\
\text { solving abilities }\end{array}$} & \multirow{3}{*}{$\begin{array}{l}\text { Current } \\
\text { student }\end{array}$} & \multirow[t]{3}{*}{2.74} & Employer & 3.00 & $-.257^{*}$ & .058 & .001 \\
\hline & & & Alumni & 3.04 & $-.297 *$ & .059 & .000 \\
\hline & & & $\begin{array}{l}2018 \\
\text { Graduates } \\
\text { and Final- } \\
\text { year }\end{array}$ & 2.95 & $-.206 *$ & .056 & .009 \\
\hline
\end{tabular}




\begin{tabular}{|c|c|c|c|c|c|c|c|}
\hline $\begin{array}{l}\text { Dependent } \\
\text { Variable }\end{array}$ & (I) Group & $\begin{array}{c}\text { Mean } \\
(\mathrm{I})\end{array}$ & (J) Group & $\begin{array}{c}\text { Mean } \\
(J)\end{array}$ & $\begin{array}{c}\text { Mean } \\
\text { Difference } \\
(I-J)\end{array}$ & $\begin{array}{l}\text { Std. } \\
\text { Error }\end{array}$ & Sig. \\
\hline \multirow{3}{*}{$\begin{array}{l}\text { GC10 - Ability } \\
\text { to initiate, } \\
\text { plan, organise, } \\
\text { implement } \\
\text { and evaluate } \\
\text { courses of } \\
\text { action }\end{array}$} & \multirow{3}{*}{$\begin{array}{l}\text { Current } \\
\text { student }\end{array}$} & \multirow[t]{3}{*}{2.54} & Employer & 2.84 & $-.295^{*}$ & .068 & .001 \\
\hline & & & Alumni & 2.88 & $-.338 *$ & .069 & .000 \\
\hline & & & $\begin{array}{l}2018 \\
\text { Graduates } \\
\text { and Final- } \\
\text { year }\end{array}$ & 2.80 & $-.263^{*}$ & .066 & .003 \\
\hline \multirow{4}{*}{$\begin{array}{l}\text { GC11 - Ability } \\
\text { to conduct } \\
\text { research }\end{array}$} & \multirow{4}{*}{$\begin{array}{l}\text { Current } \\
\text { student }\end{array}$} & \multirow[t]{4}{*}{2.50} & Employer & 2.91 & $-.404^{*}$ & .071 & .000 \\
\hline & & & Alumni & 2.75 & $-.251 *$ & .072 & .016 \\
\hline & & & $\begin{array}{l}2018 \\
\text { Graduates } \\
\text { and Final- } \\
\text { year }\end{array}$ & 2.79 & $-.292 *$ & .068 & .001 \\
\hline & & & $\begin{array}{l}\text { Lecturer, } \\
\text { Dean, } \\
\text { Rector }\end{array}$ & 2.84 & $-.341 *$ & .107 & .039 \\
\hline \multirow{4}{*}{$\begin{array}{l}\text { GC12 - Ability } \\
\text { to demonstrate } \\
\text { leadership } \\
\text { attributes }\end{array}$} & \multirow{3}{*}{$\begin{array}{l}\text { Current } \\
\text { student }\end{array}$} & \multirow[t]{3}{*}{2.53} & Employer & 2.95 & $-.416^{*}$ & .068 & .000 \\
\hline & & & Alumni & 2.90 & $-.365^{*}$ & .070 & .000 \\
\hline & & & $\begin{array}{l}2018 \\
\text { Graduates } \\
\text { and Final- } \\
\text { year }\end{array}$ & 2.85 & $-.315^{*}$ & .066 & .000 \\
\hline & $\begin{array}{l}\text { Lecturer, } \\
\text { Dean, } \\
\text { Rector }\end{array}$ & 2.57 & Employer & 2.95 & $-.381 *$ & .108 & .015 \\
\hline $\begin{array}{l}\text { GC13 - Ability } \\
\text { to apply } \\
\text { knowledge in } \\
\text { practice }\end{array}$ & $\begin{array}{l}\text { Current } \\
\text { student }\end{array}$ & 2.83 & Employer & 3.01 & $-.186 *$ & .059 & .042 \\
\hline
\end{tabular}

In general, for $11 \mathrm{GCs}$ the mean difference in achievement is significant between groups (except for GC4 and GC7). In ANOVA analysis and the Scheffe test:

- GC1 - ability to work collaboratively and effectively in diverse contexts 
The mean difference between the employer group and the current student group is 0.263 , significant at the 0.000 level; between alumni and current students the mean difference is 0.314 , significant at the 0.000 level.

The highest mean value (3.11) is for the alumni group; the lowest mean value (2.80) is for the current student group.

- GC2 - ability to use information and communication technology purposefully and responsibly

The mean difference between the employer group and the current student group is 0.266 , significant at the 0.000 level; between alumni and current students it is 0.265 , significant at the 0.001 level.

The highest mean value (3.07) is for both the employer group and the alumni group. The lowest mean value (2.80) is for both the lecturer, dean, rector group and the group of current students.

- GC3 - ability to uphold professional, moral and ethical values

The mean difference between the employer group and the lecturer, dean, rector group is 0.308 , significant at the 0.017 level; between the alumni and the 2018 graduates and final-year student group it is 0.194 , significant at the 0.039 level; between alumni and the lecturer, dean, rector group it is 0.455 , significant at the $0.000 \mathrm{level}$; and between the current student group and lecturer, dean, rector group it is 0.305 , significant at the 0.011 level.

The highest mean value is 3.42 for the alumni group, and the lowest mean value (2.96) is for the lecturer, dean, rector group.

- GC5 - ability to communicate clearly and effectively

The mean difference between the employer group and the current student group is 0.255 , significant at the 0.001 level; between alumni and current students it is 0.414 , significant at the 0.000 level; between the 2018 graduate/final-year group and the current student group it is 0.279 , significant at the 0.001 level.

The highest mean value (3.15) is for the alumni group; the lowest mean value (2.73) is for the current student group.

- GC6 - ability to think critically, reflectively and innovatively

The mean difference between the employer group and the current student group is 0.304 , significant at the 0.000 level; between the alumni and current 
student group it is 0.429 , significant at the 0.000 level; and between the 2018 graduates/final-year student group and the current student group it is 0.282 , significant at the 0.001 level.

The highest mean value (3.00) is for the alumni group; the lowest mean value (2.57) is for the current student group.

- GC8 - ability to carry out lifelong learning and continual professional development

The mean difference between the employer group and the current student group is 0.327 , significant at the 0.000 level; and between the alumni and the current student group it is 0.294 , significant at the 0.000 level.

The highest mean value (3.10) is for the employer group; the lowest mean value (2.77) is for the group of current students.

- GC9 - demonstrate problem solving abilities

The mean difference between the employer group and the current student group is 0.257 , significant at the 0.001 level; between the alumni and current student groups it is 0.297 , significant at the 0.000 level; between the 2018 graduate/final-year student group and current student group it is 0.206 , significant at the 0.009 level.

The highest mean value (3.04) is for the alumni group; the lowest mean value (2.74) is for the current student group.

- GC10 - ability to initiate, plan, organise, implement and evaluate courses of action

The mean difference between the employer group and the current student group is 0.295 , significant at the 0.001 level; between the alumni and current student groups it is 0.338 , significant at the 0.000 level; between the 2018 graduates/final-year student group and the current student group it is 0.263 , significant at the 0.003 level.

The highest mean value (2.88) is for the alumni group; the lowest mean value (2.54) is for the current student group.

- GC11 - ability to conduct research

The mean difference between the employer group and the current student group is 0.404 , significant at the 0.000 level; between the alumni and current 
student groups it is 0.251 , significant at the 0.016 level; between the 2018 graduate/final-year student group and the current student group it is 0.292 , significant at the 0.001 level; between the lecturer, dean, rector group and the current student group it is 0.341 , significant at the 0.039 level.

The highest mean value (2.91) is for the employer group; the lowest mean value (2.50) is for the current student group.

- GC12 - ability to demonstrate leadership attributes

The mean difference between the employer group and the lecturer, dean, rector group is 0.381 , significant at the 0.015 level; between the employer group and the current student group it is 0.416 , significant at the 0.000 level; between the alumni and current student groups it is 0.365 , significant at the 0.000 level. The mean difference between the 2018 graduate/final-year student group and the current student group is 0.315 , significant at the 0.000 level.

The highest mean value (2.95) is for the employer group. The lowest mean value (2.53) is for the current student group.

- GC13 - ability to apply knowledge in practice

The mean difference between the employer group and the current student group is 0.186 , significant at the 0.042 level.

The highest mean value (3.01) is for the employer group; the lowest mean value (2.83) is for the current student group.

Since the TASE project did not include a group of recent graduates, and because a relatively small group of lecturers, deans, and rectors participated in the current research, the following sections compare the findings from the surveys among employers, alumni and current students to the findings from similar groups in the TASE project.

\section{V.2. Employer rating and ranking}

\section{IV.2.1. Importance - Employers}

Employers of VNU graduates rated the importance of $13 \mathrm{GCs}$ at a higher level than they did graduates' achievement of them.

Employers of VNU graduates ranked all GCs on a lower level of importance than did employers for all areas of the TASE project. ${ }^{46}$ Employers

${ }^{46}$ Tuning Academy, “Tuning Asia - South East, Second Meeting Report,” 20. 
of both groups rated GC3 (the ability to uphold professional, moral and ethical values) and GC13 (the ability to apply knowledge in practice) as the first and second most important competences, respectively. Both GC7 (the ability to understand, value and respect diversity and multiculturalism) and GC11 (the ability to conduct research) were the two least important in the ratings of the two groups of employers.

However, while employers of VNU graduates rated GC8 (the ability to engage in lifelong learning and continual professional development) and GC1 (the ability to work collaboratively and effectively in diverse contexts) as the seventh and eighth most important abilities, respectively, TASE employers rated them in third and fourth place.

GC9 was rated fourth in importance by employers of VNU graduates, but seventh by TASE employers.

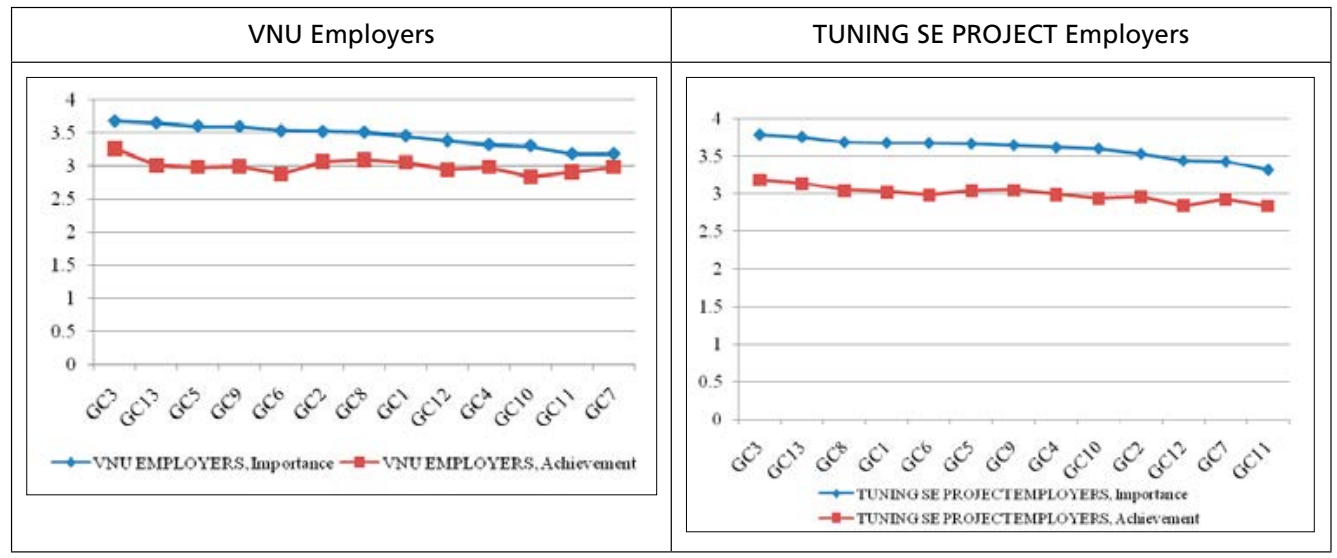

Figure 1

Employers - Ratings

Information generated from "Tuning Asia - South East, Second meeting Report"47

In the 4 Likert scale categories $(1=$ none, $2=$ weak, $3=$ considerable, 4 $=$ strong), $\mathrm{VNU}$ employers rated all $13 \mathrm{GCs}$ as of great importance (4, strong) - higher than considerable (3). Of highest importance was GC3 (ability to uphold professional, moral and ethical values) (mean $=3.69$ ), second was

47 Tuning Academy, "Tuning Asia - South East, Second meeting Report," http:// tuningasia-southeast.org/second-meeting/. 
GC13 (ability to apply knowledge in practice) (mean $=3.66$ ), lowest were GC11 (ability to conduct research) and GC7 (ability to understand, value, and respect diversity and multiculturalism) (mean for both $=3.19$ ).

\section{Table 4}

\section{Employers of VNU graduates - RATING vs RANKING}

\begin{tabular}{|c|c|c|}
\hline $\begin{array}{c}\text { Employers of VNU } \\
\text { graduates rate importance } \\
\text { of GCs }\end{array}$ & $\begin{array}{c}\text { Employers of VNU } \\
\text { graduates rank priority } \\
\text { of GCs (see details in the } \\
\text { Annex) }\end{array}$ & $\begin{array}{c}\text { Employers of VNU } \\
\text { graduates rate achievement } \\
\text { of GCs }\end{array}$ \\
\hline $\begin{array}{l}\text { 1st - GC3, ability to } \\
\text { uphold professional, } \\
\text { moral and ethical values }\end{array}$ & $\begin{array}{l}\text { 1st - GC13, ability to } \\
\text { apply knowledge into } \\
\text { practice }\end{array}$ & $\begin{array}{l}\text { 1st - GC3, ability to } \\
\text { uphold professional, } \\
\text { moral and ethical values }\end{array}$ \\
\hline $\begin{array}{l}\text { 2nd - GC13, ability to } \\
\text { apply knowledge in } \\
\text { practice }\end{array}$ & $\begin{array}{l}\text { 2nd - GC5, ability to } \\
\text { communicate clearly } \\
\text { and effectively }\end{array}$ & $\begin{array}{l}\text { 2nd - GC8, ability to } \\
\text { carry out lifelong } \\
\text { learning and } \\
\text { continual professional } \\
\text { development }\end{array}$ \\
\hline $\begin{array}{l}\text { 3rd - GC5, ability to } \\
\text { communicate clearly } \\
\text { and effectively }\end{array}$ & $\begin{array}{l}\text { 3rd - GC1, ability to } \\
\text { work collaboratively and } \\
\text { effectively in diverse } \\
\text { contexts }\end{array}$ & $\begin{array}{l}\text { 3rd - GC2, ability } \\
\text { to use information } \\
\text { and communication } \\
\text { technology purposefully } \\
\text { and responsibly }\end{array}$ \\
\hline $\begin{array}{l}\text { 4th - GC9, demonstrate } \\
\text { problem-solving abilities }\end{array}$ & $\begin{array}{l}\text { 4th - GC9, demonstrate } \\
\text { problem-solving abilities }\end{array}$ & $\begin{array}{l}\text { 4th - GC1, ability to } \\
\text { work collaboratively and } \\
\text { effectively in diverse } \\
\text { contexts }\end{array}$ \\
\hline $\begin{array}{l}5 \text { th - GC6, ability } \\
\text { to think critically, } \\
\text { reflectively and } \\
\text { innovatively }\end{array}$ & $\begin{array}{l}\text { 5th - GC3, ability to } \\
\text { uphold professional, } \\
\text { moral and ethical values }\end{array}$ & $\begin{array}{l}\text { 5th - GC13, ability to } \\
\text { apply knowledge in } \\
\text { practice }\end{array}$ \\
\hline 6 th - GC2 & 6th - GC8 & 6th - GC9 \\
\hline 7th - GC8 & 7th - GC2 & 7th - GC4 \\
\hline 8th - GC1 & 8th - GC12 & 8th - GC5 \\
\hline 9th - GC12 & 9th - GC6 & 9th - GC7 \\
\hline 10th - GC4 & 10th - GC11 & 10th - GC12 \\
\hline 11th - GC10 & 11th - GC10 & 11th - GC11 \\
\hline 12th - GC11 & 12th - GC4 & 12th - GC6 \\
\hline 13th - GC7 & 13th - GC7 & 13th - GC10 \\
\hline
\end{tabular}


Employers of VNU graduates rated GC3 (the ability to uphold professional, moral and ethical values) as first in importance, the fifth priority, and in first place for graduate achievement. They rated GC5 (the ability to communicate clearly and effectively) as third in importance and the second priority but rated it eighth in graduate achievement. GC9 (demonstrate problem-solving abilities) they ranked fourth in importance, the fourth priority, but sixth on the scale of graduate achievement. GC6 (the ability to think critically, reflectively and innovatively) they rated fifth in importance, the ninth priority, but only $12^{\text {th }}$ in graduate achievement.

VNU employers rated GC10 (the ability to initiate, plan, organise, implement and evaluate a course of action) and GC11 (the ability to conduct research) at a low level of importance, a low priority, and low on the scale of graduate achievement as well.

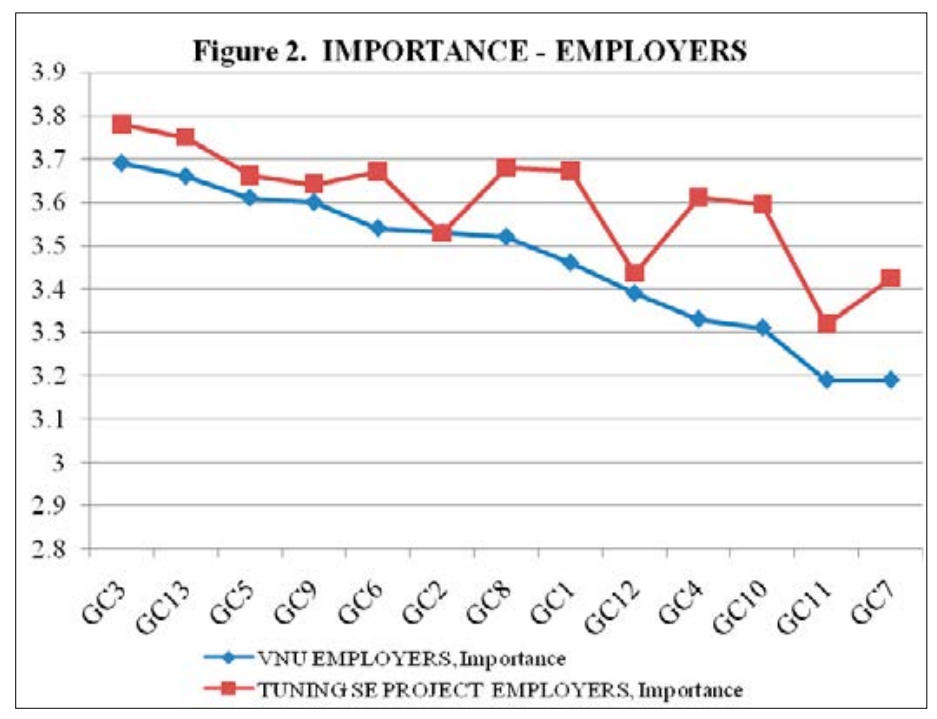

Figure 2

Importance - Employers

\section{IV .2.2. Achievement - Employers}

Both VNU employers and Tuning-SE project employers rated graduates' achievement of GC3 (the ability to uphold professional, moral and ethical values) in first place. 
Employers of VNU graduates rated VNU graduate achievement of GC13, GC9, GC5, GC6, and GC10 at lower levels than did TASE employers, and rated VNU graduate achievement of GC3, GC8, GC2, GC1, GC7, GC12, GC11 at higher levels than did TASE-project employers.

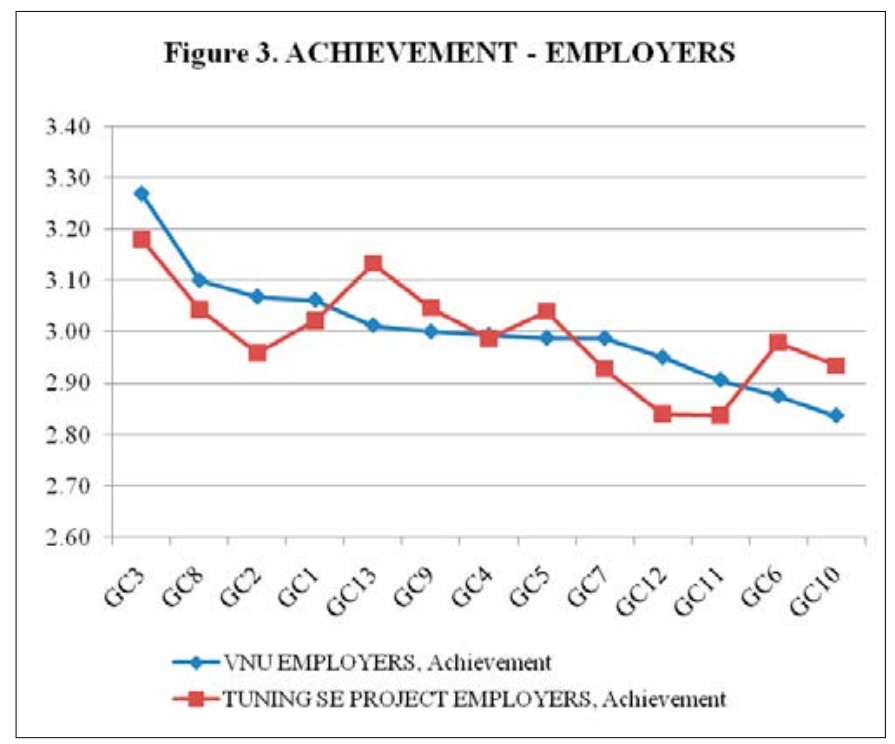

Figure 3

Achievement - Employers

VNU employers rated only six general competences in the "considerable" category of achievement, and the other seven GCs lower. Just as they rated GC3 as of highest importance, they also considered it the graduates' highest achievement (mean $=3.27$ ). GC8 (ability to engage in lifelong learning and continual professional development) was rated the second to highest achievement (mean $=3.10)$. GC10 (ability to initiate, plan, organise, implement and evaluate courses of action) was rated lowest (mean $=2.83$ ), and GC6 (ability to think critically, reflectively and innovatively) was considered the second to lowest achievement $($ mean $=2.88)$, though it was rated as fifth in importance (mean $=3.54$ ).

Employers of VNU graduates rated GC13 as second in importance but rated graduate achievement of this competence in fifth place. GC8 they ranked seventh in importance, however, and graduates' achievement of it in second place. GC11 was ranked $13^{\text {th }}$ in importance and $10^{\text {th }}$ in graduate 
achievement. They rated GC10 as $10^{\text {th }}$ in importance and $13^{\text {th }}$ on level of achievement.

\section{V.3. Students - rating and ranking}

\section{IV.3.1. Importance - Student}

VNU students rated the importance of all GCs at a higher level than their achievement of them. This is similar to student ratings in the Tuning project.

Both VNU Students and TASE project students ranked GC13 as highest in importance.

VNU students rated GC7 at the lowest level, which is similar to the employers' rating. Meanwhile, Tuning-SE project students rated GC11 at the lowest level.

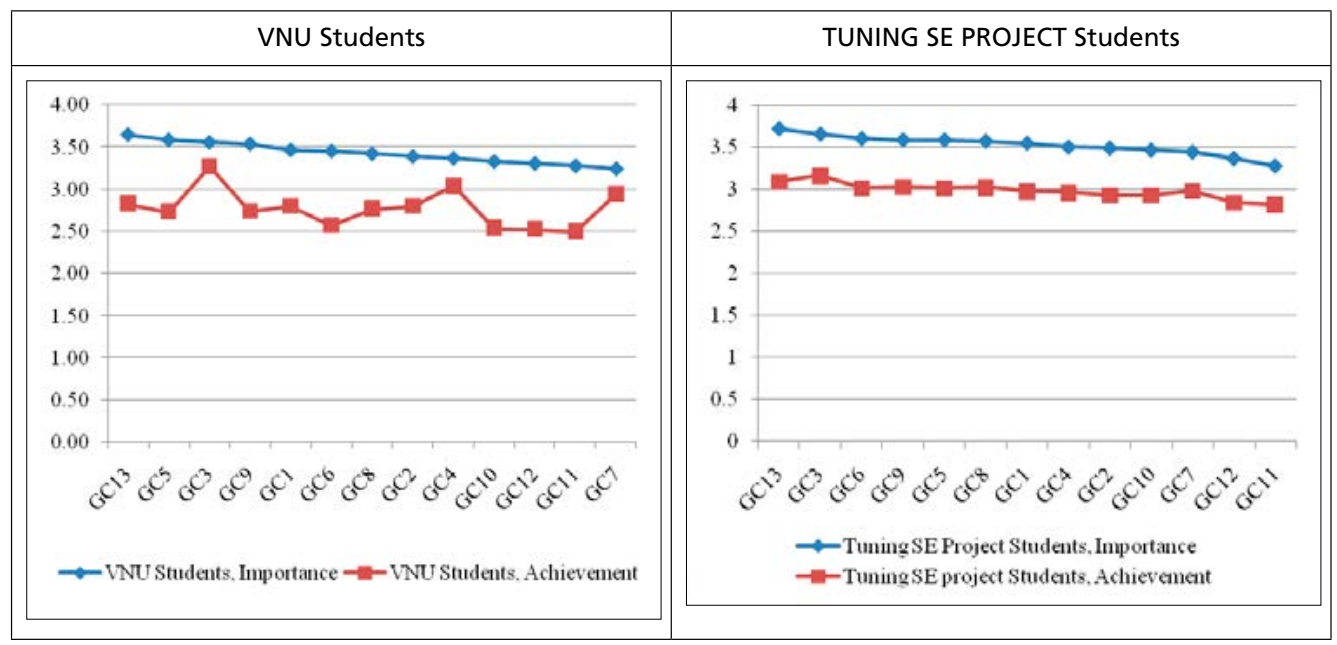

Figure 4

Students - Rating

VNU students rated all GCs at a lower level of importance than did students in the Tuning-SE project. ${ }^{48}$

${ }^{48}$ Tuning Academy, “Tuning Asia - South East, Second Meeting Report,” 22. 


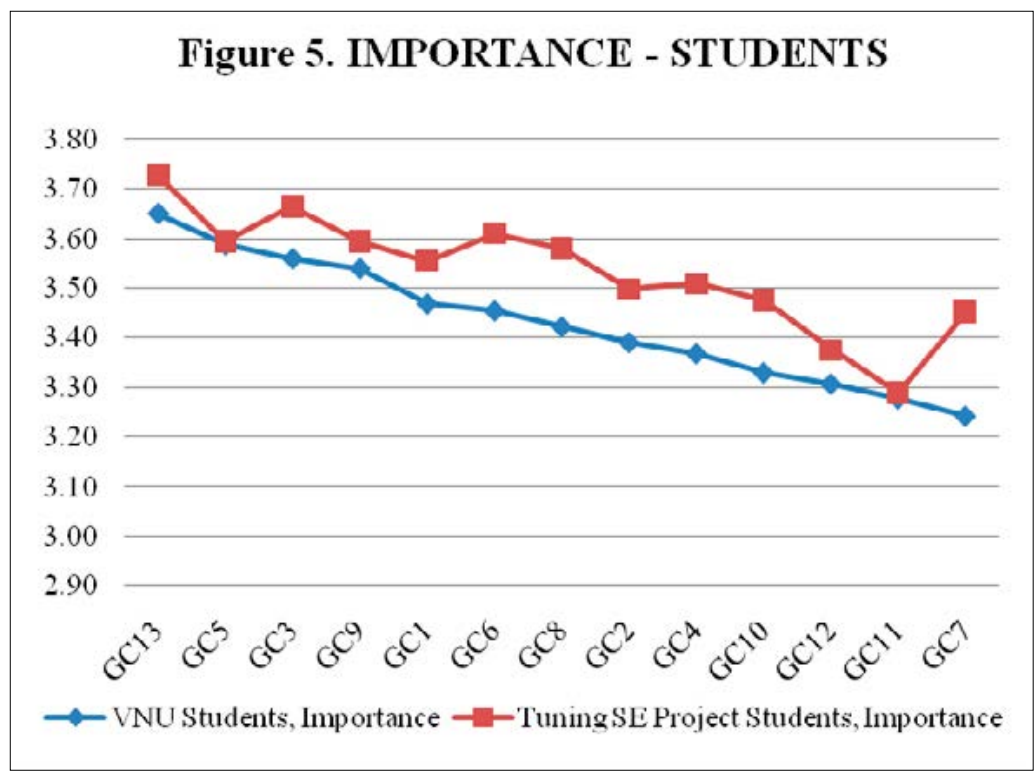

Figure 5

Importance - Students

Like VNU employers, VNU students rated all 13 GCs as of high importance - higher than the "considerable" category. Highest was GC13 (ability to apply knowledge in practice) (mean $=3.65)$. Second was GC5 (ability to communicate clearly and effectively) (mean $=3.59$ ), lowest was GC7 (ability to understand, value, and respect diversity and multiculturalism) (mean $=3.24)$, and second to lowest was GC11 (ability to conduct research) $($ Mean $=3.28)$.

\section{IV.3.2. Achievement - Students}

VNU students ranked only two general competences in the "considerable" category of achievement, and the other 11 competences lower. GC3 was rated as the highest achievement (mean $=3.27$ ), GC4 (ability to demonstrate responsibility and accountability towards society and environment) was second to highest (Mean $=3.04$ ). GC11 (ability to conduct research) was rated lowest $($ Mean $=2.50)$, and GC12 (ability to demonstrate leadership attributes) was second to lowest $($ mean $=2.53)$. 




Figure 6

Achievement - Students

VNU student ratings of their achievement of 11 general competences (except for GC3 and GC4) were lower than those of students in the TASE project. The widest gap was for GC6, followed by GC10. Both student groups (VNU and TASE project) rated their achievement of GC3 at the highest level and GC11 at the lowest. VNU students rated their achievement of GC13 in fourth place. Meanwhile, TASE project students rated GC13 as second highest in their achievement. However, both groups rated GC13 as most important.

VNU students rated GC5 as second in importance, first priority, but ninth in their achievement; GC9 as fourth in importance, third priority, but eighth in their achievement.

VNU students rated GC13 as first in importance, second priority, and fourth in their achievement. They ranked GC3 as third in importance, sixth priority, and first in their achievement.

VNU students' rating for both GC7 and GC4: low in importance but high in their achievement.

GC7: $13^{\text {th }}$ in importance, third in their achievement.

GC4: ninth in importance, second in achievement. 
Table 5

VNU students - RATING vs RANKING

\begin{tabular}{|c|c|c|}
\hline $\begin{array}{l}\text { VNU students rate } \\
\text { importance of GCs }\end{array}$ & $\begin{array}{c}\text { VNU students rank priority } \\
\text { of GCs (see details in } \\
\text { Annex) }\end{array}$ & $\begin{array}{l}\text { VNU students rate } \\
\text { achievement of GCs }\end{array}$ \\
\hline $\begin{array}{l}\text { 1st - GC13, ability to } \\
\text { apply knowledge in } \\
\text { practice }\end{array}$ & $\begin{array}{l}\text { 1st - GC5, ability to } \\
\text { communicate clearly } \\
\text { and effectively }\end{array}$ & $\begin{array}{l}\text { 1st - GC3, ability to } \\
\text { uphold professional, } \\
\text { moral and ethical values }\end{array}$ \\
\hline $\begin{array}{l}\text { 2nd - GC5, ability to } \\
\text { communicate clearly } \\
\text { and effectively }\end{array}$ & $\begin{array}{l}\text { 2nd - GC13, ability to } \\
\text { apply knowledge in } \\
\text { practice }\end{array}$ & $\begin{array}{l}\text { 2nd - GC4, ability } \\
\text { to demonstrate } \\
\text { responsibility and } \\
\text { accountability towards } \\
\text { society and environment }\end{array}$ \\
\hline $\begin{array}{l}\text { 3rd - GC3, ability to } \\
\text { uphold professional, } \\
\text { moral and ethical values }\end{array}$ & $\begin{array}{l}\text { 3rd-GC9, demonstrate } \\
\text { problem-solving abilities }\end{array}$ & $\begin{array}{l}\text { 3rd - GC7, ability to } \\
\text { understand, value, and } \\
\text { respect diversity and } \\
\text { multiculturalism }\end{array}$ \\
\hline $\begin{array}{l}\text { 4th - GC9, demonstrate } \\
\text { problem solving abilities }\end{array}$ & $\begin{array}{l}\text { 4th - GC6, ability } \\
\text { to think critically, } \\
\text { reflectively and } \\
\text { innovatively }\end{array}$ & $\begin{array}{l}\text { 4th - GC13, ability to } \\
\text { apply knowledge in } \\
\text { practice }\end{array}$ \\
\hline $\begin{array}{l}\text { 5th - GC1, ability to } \\
\text { work collabouratively } \\
\text { and effectively in } \\
\text { diverse contexts }\end{array}$ & $\begin{array}{l}\text { 5th - GC1, ability to } \\
\text { work collabouratively } \\
\text { and effectively in } \\
\text { diverse contexts }\end{array}$ & $\begin{array}{l}\text { 5th - GC2, ability } \\
\text { to use information } \\
\text { and communication } \\
\text { technology purposefully } \\
\text { and responsibly }\end{array}$ \\
\hline 6th - GC6 & 6th - GC3 & 6th - GC1 \\
\hline 7th - GC8 & 7th - GC8 & 7th - GC8 \\
\hline 8th - GC2 & 8th - GC2 & 8th - GC9 \\
\hline 9th - GC4 & 9th - GC10 & 9th - GC5 \\
\hline 10th - GC10 & 10th - GC12 & 10th - GC6 \\
\hline 11 th - GC12 & 11th - GC11 & 11th - GC10 \\
\hline 12th - GC11 & 12th - GC4 & 12th - GC12 \\
\hline 13th - GC7 & 13th - GC7 & 13th - GC11 \\
\hline
\end{tabular}




\section{V.4. Alumni-rating and ranking}

\section{IV .4.1. Importance - Alumni}

As with the results of the various Tuning projects, VNU alumni rated the importance of all GCs more highly than their achievement of them. Both groups of alumni rated GC13 (ability to apply knowledge in practice) as of greatest importance, a rating similar to that of the students.

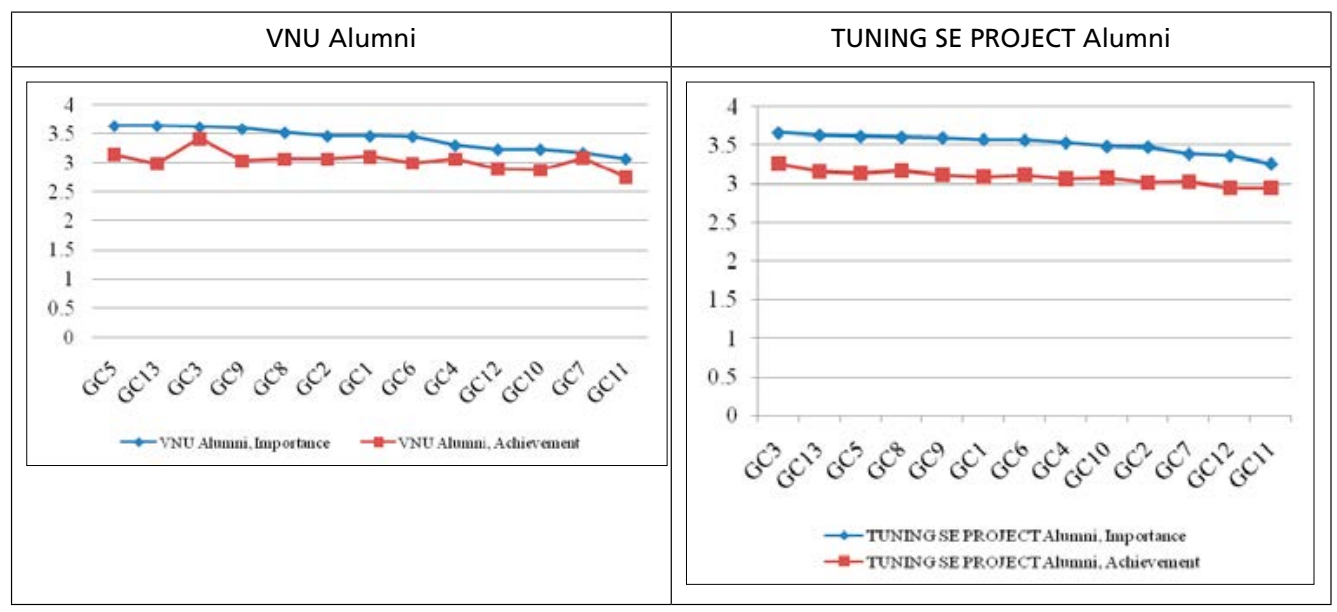

Figure 7

Alumni - Ratings

VNU alumni rated 12 general competences at a lower level of importance than alumni in the Tuning-SE Project did ${ }^{49}$ except for GC5 (ability to communicate clearly and effectively). The widest gaps are for GC4, GC10, GC7 and GC11:

- GC4 - ability to demonstrate responsibility and accountability towards society and environment

- GC7 - ability to understand, value, and respect diversity and multiculturalism

- GC10 - ability to initiate, plan, organise, implement and evaluate courses of action

49 Tuning Academy, “Tuning Asia - South East, Second Meeting Report,” 24. 
- GC11 - ability to conduct research

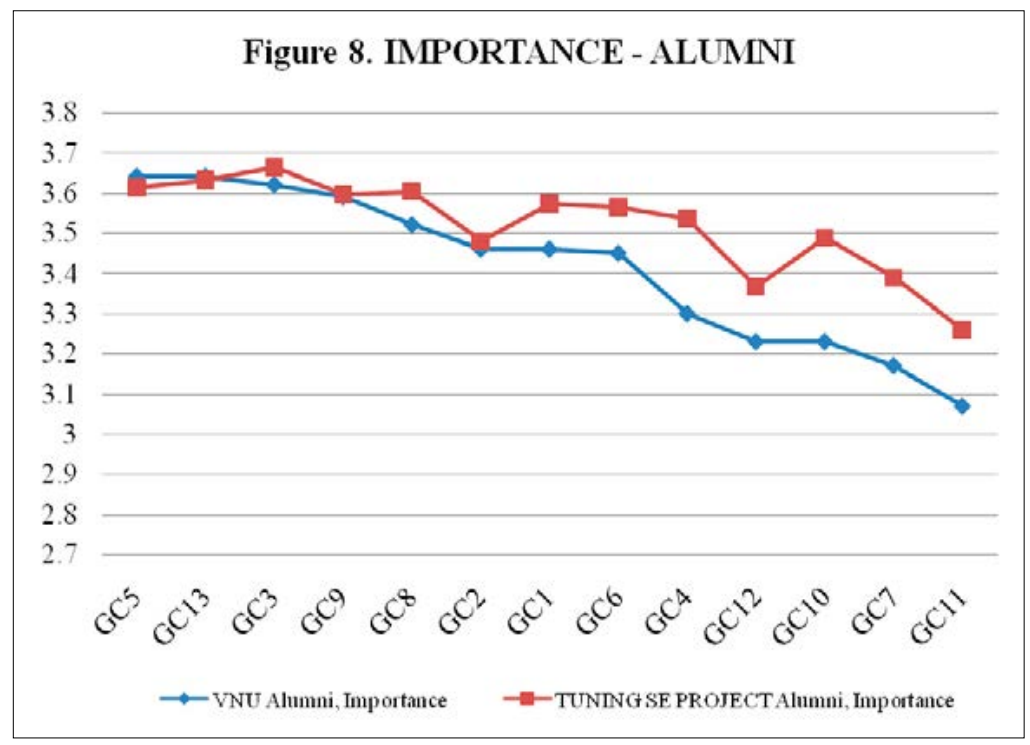

Figure 8

Importance - Alumni

Like VNU employers and VNU students, VNU alumni also rated all 13 GCs as of high importance - higher than the "considerable" category (4). Ranked as of highest importance were GC13 (ability to apply knowledge in practice) and GC5 (ability to communicate clearly and effectively) (mean for both $=3.64)$. Lowest was GC11 (ability to conduct research) $($ mean $=3.07)$, and GC7 (ability to understand, value, and respect diversity and multiculturalism) was ranked second to lowest (mean $=3.17$ ).

\section{IV.4.2. Achievement - Alumni}

VNU alumni rating - high importance but low achievement

VNU alumni rated GC13 and GC9 high in importance but low in their achievement:

- GC13 - ability to apply knowledge in practice (second in importance, $10^{\text {th }}$ in their achievement) 
- GC9 - ability to demonstrate problem-solving abilities (fourth in importance, eighth in their achievement)

VNU alumni rating - high importance and high achievement

VNU alumni rated both CG3 and GC5 as high in importance and achievement:

- GC3 - ability to uphold professional, moral and ethical values (third in importance, first in their achievement)

- GC5 - ability to communicate clearly and effectively (first in importance, second in their achievement)

VNU alumni rating - low in importance and low in achievement

VNU alumni rated CG12, GC10 and GC11 as both low in importance and in their achievement:

- GC12 - ability to demonstrate leadership attributes $\left(10^{\text {th }}\right.$ in importance, $11^{\text {th }}$ in their achievement)

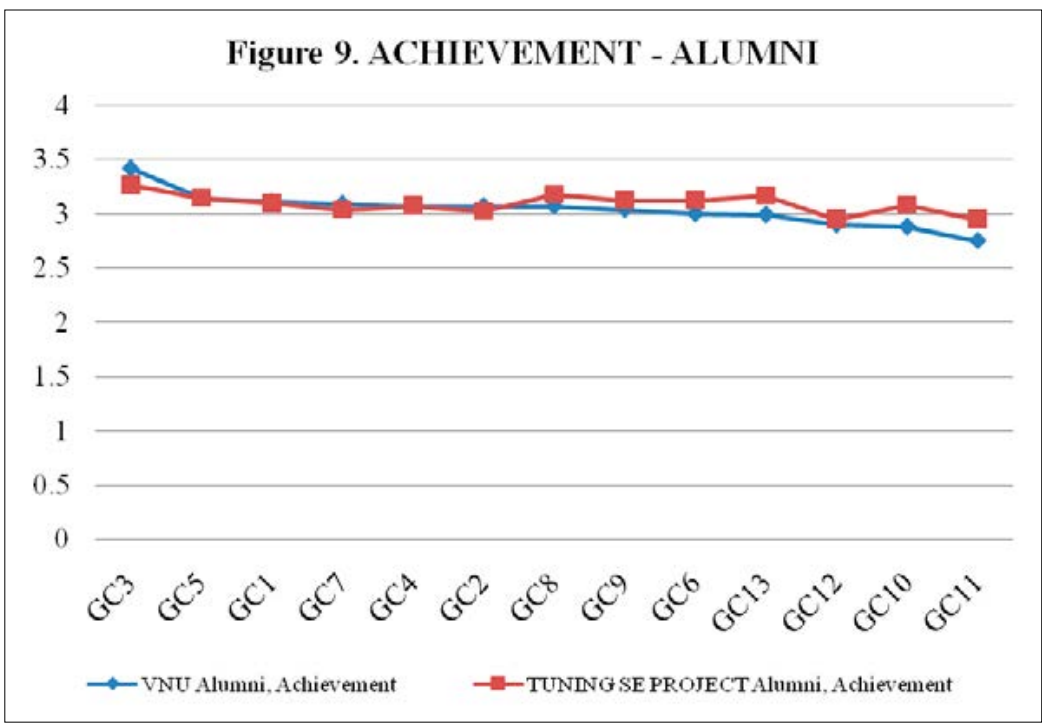

Figure 9

Achievement - Alumni

Tuning Journal for Higher Education 
- GC10 - ability to initiate, plan, organise, implement and evaluate courses of action ( $11^{\text {th }}$ in importance, $12^{\text {th }}$ in their achievement)

- GC11 - ability to conduct research $\left(13^{\text {th }}\right.$ in importance, $13^{\text {th }}$ in their achievement)

VNU alumni gave a similar rating to their achievement of GCs as did alumni of the Tuning-SE project.

Like the rating given by employers and students, alumni rated their achievement of GC3 at the highest level.

Both alumni and students rated their achievement of GC11 at the lowest level.

VNU alumni rated nine general competences in the "considerable" (4) category of achievement, and the other four GCs lower. GC3 was rated as their highest achievement (mean $=3.42)$, GC5 (ability to communicate clearly and effectively) was second (mean $=3.15$ ). GC11 (ability to conduct research) was rated lowest (mean $=2.75$ ), and GC10 (ability to initiate, plan, organise, implement and evaluate courses of action) was second to lowest in achievement $($ mean $=2.88)$.

\section{Table 6}

VNU alumni - RATING vs RANKING

\begin{tabular}{|l|l|l|}
\hline \multicolumn{1}{|c|}{$\begin{array}{c}\text { VNU alumni rate } \\
\text { importance of GCs }\end{array}$} & $\begin{array}{c}\text { VNU alumni rank priority } \\
\text { of GCs (see details in the } \\
\text { Annex) }\end{array}$ & \multicolumn{1}{c|}{$\begin{array}{c}\text { VNU alumni rate } \\
\text { achievement of GCs }\end{array}$} \\
\hline $\begin{array}{l}\text { 1st - GC5, ability to } \\
\text { communicate clearly } \\
\text { and effectively }\end{array}$ & $\begin{array}{l}\text { 1st - GC5, ability to } \\
\text { communicate clearly } \\
\text { and effectively }\end{array}$ & $\begin{array}{l}\text { 1st - GC3, ability to } \\
\text { uphold professional, } \\
\text { moral and ethical values }\end{array}$ \\
\hline $\begin{array}{l}\text { 2nd - GC13, ability to } \\
\text { apply knowledge in } \\
\text { practice }\end{array}$ & $\begin{array}{l}\text { 2nd - GC9, demonstrate } \\
\text { problem-solving abilities }\end{array}$ & $\begin{array}{l}\text { 2nd - GC5, ability to } \\
\text { communicate clearly } \\
\text { and effectively }\end{array}$ \\
\hline $\begin{array}{l}\text { 3rd - GC3, ability to } \\
\text { uphold professional, } \\
\text { moral and ethical values }\end{array}$ & $\begin{array}{l}\text { 3rd - GC13, ability to } \\
\text { apply knowledge in } \\
\text { practice }\end{array}$ & $\begin{array}{l}\text { 3rd - GC1, ability to } \\
\text { work collaboratively and } \\
\text { effectively in diverse } \\
\text { contexts }\end{array}$ \\
\hline $\begin{array}{l}\text { 4th - GC9, demonstrate } \\
\text { problem-solving abilities }\end{array}$ & $\begin{array}{l}\text { 4th - GC3, ability to } \\
\text { uphold professional, } \\
\text { moral and ethical values }\end{array}$ & $\begin{array}{l}\text { 4th - GC7, ability to } \\
\text { understand, value, and } \\
\text { respect diversity and } \\
\text { multiculturalism }\end{array}$ \\
\hline
\end{tabular}


$\ldots / \ldots$

\begin{tabular}{|l|l|l|}
\hline \multicolumn{1}{|c|}{$\begin{array}{c}\text { VNU alumni rate } \\
\text { importance of GCs }\end{array}$} & $\begin{array}{c}\text { VNU alumni rank priority } \\
\text { of GCs (see details in the } \\
\text { Annex) }\end{array}$ & \multicolumn{1}{|c|}{$\begin{array}{c}\text { VNU alumni rate } \\
\text { achievement of GCs }\end{array}$} \\
\hline $\begin{array}{l}\text { 5th - GC8, ability to } \\
\text { carry out lifelong } \\
\text { learning and } \\
\text { continual professional } \\
\text { development }\end{array}$ & $\begin{array}{l}\text { 5th - GC6, ability } \\
\text { to think critically, } \\
\text { reflectively and } \\
\text { innovatively }\end{array}$ & $\begin{array}{l}\text { 5th - GC4, ability } \\
\text { to demonstrate } \\
\text { responsibility and } \\
\text { accountability towards } \\
\text { society and environment }\end{array}$ \\
\hline 6th - GC2 & 6th - GC1 & 6th - GC2 \\
\hline 7th - GC1 & 7th - GC8 & 7th - GC8 \\
\hline 8th - GC6 & 8th - GC2 & 8th - GC9 \\
\hline 9th - GC4 & 9th - GC12 & 9th - GC6 \\
\hline 10th - GC12 & 10th - GC10 & 10th - GC13 \\
\hline 11th - GC10 & 11th - GC11 & 11th - GC12 \\
\hline 12th - GC7 & 12th - GC4 & 12th - GC10 \\
\hline 13th - GC11 & 13th - GC7 & 13th - GC11 \\
\hline
\end{tabular}

In general, employers, students and alumni of VNU and of the Tuning-SE project rated the importance of all GCs more highly than graduate achievement of them. Employers, students and alumni of VNU and of the Tuning-SE project rated graduates' achievement of GC3 (ability to uphold professional, moral and ethical values) at the highest level. Alumni and students rated graduates' achievement of GC11 (ability to conduct research) at the lowest level.

\section{V.5. Semi-structured interviews}

The interviews with current students and alumni elicited their concern about "showing initiative", "planning", and "organising". Though this competence was essential for carrying out their tasks in the workplace, their university lessons included no activities to develop this competence.

IV .5.1. Current students' comments on the importance of the general competences and their achievement of them

In the semi-structured interviews, informant 1 (male, alumnus, school teacher, 25 years old) said he understood the importance of showing initiative 
in his work, but he rated his performance of this competence poorly. Assuming that it was closely linked with personal aptitude, he saw this competence as an attribute of leadership and said that he did not consider himself a leader in his class because he had not initiated or organised any activities. Therefore, he did not believe he had achieved this competence satisfactorily.

My job requires me to show initiative, but I failed to do so, for example, by organising an excursion or field trip. If I had done so, my students would be happier about going to school. I think I am poor at this competence. When I was studying at the university, there was almost no activity to develop this competence. I was not a leader in my class and did not organise anything. (Informant 1, male, alumnus, teacher, 25 years old)

As a teacher, informant 1 needed to train his students in the attributes of citizenship, disciplinary knowledge, and practical application skills but he did not feel competent to initiate new ideas. In the long run, his students would become less competent in these skills and attributes.

Informant 2 (female, 37 years old), who was working on her second degree, shared similar feelings of lack of confidence about her performance of this competence. Her university classes were scheduled for evenings and weekends, so there were no extra-curricular activities for students.

I am least confident about competence 10. I am doing my second degree but there are no activities at the university to develop this competence. (Informant 2, female, current second degree student, 37 years old)

Like Informant 1, this woman was not satisfied with her GC10 (ability to initiate, plan, organise, implement and evaluate courses of action). This weakness was also clear in the way she insisted that learning activities should develop these skills. As Barrie argued, the attribute of personal and intellectual autonomy and skills in application belong to his "translation" level of generic attributes, which are transferable and transcend disciplinary boundaries. ${ }^{50}$ Since informant 2 was in her second degree, she should be competent in these skills. Her earlier education had not trained her ability to initiate, plan, organise, implement and evaluate courses of action.

Other informants also thought that there were ways to develop this competence, such as doing practicums, problem-solving activities or project work. They highlighted the fact that most of the time at university, they learned from lecturers in class, so that the lecturers' teaching approach was the main and almost sole avenue for developing this competence.

50 Barrie, “Academics' understandings,” 159. 
IV .5.2. Employer and alumni comments on the relative importance of the general competences and graduates' achievement of them

To compensate for the limitations of the survey questionnaire, which did not allow employers to explain their evaluation in detail, the researcher also approached some employers for semi-structured interviews. The interviewees maintained that GC6 (ability to think critically, reflectively and innovatively) was essential, as it influenced the achievement of other competences, such as GC7 (ability to understand, value, and respect diversity and multiculturalism) and GC13 (ability to apply knowledge in practice).

For example, Informant 3 (employer, 40 years old, manager, and also an alumnus of VNU), recalled:

Critical thinking and creativity are very important because they help workers reduce their mistakes. Critical analysis of any problem reveals the real causes of error. For example, a traffic accident cannot be explained properly without critical thinking. In an organisation, one must ask questions. While studying at school, this competence is developed through presenting situations for solving in class or at home. These exercises help students develop many different abilities, including the ability to understand, value, and respect diversity and multiculturalism, cultural values and the ability to apply knowledge in practice. (Informant 3, male, alumnus, employer, manager, 40 years old)

Informant 3 saw the necessity of critical thinking and how this ability developed. From his experience, he could deduce the cause and effect relationship between this general attribute and others. His ability to think critically may also explain why he was promoted to a management role.

Other alumni confirmed that they had learnt these transferable skills through extra-curricular activities. For example, Informant 2 remarked that "these transferable skills are well developed not only through lecturers" lessons, but mostly through work practicums and the professional activities of various types of student club".

Once again, Informant 2 showed that she could not learn the "translation" attributes through teaching and learning activities. She developed them by carrying out the instructions, not just listening to them. Her route to learning was the way adults learn new skills. Her programme for second degree learners was not tailored to take advantage of the experience of learners, thus did not achieve the expected outcome.

Lecturers answering the open-ended questions suggested similar activities to develop GC6, such as: 
- Writing scientific research reports, or a final thesis

- Extra-curricular and foreign language activities

- Student discussions in class

- Teachers encouraging students to criticise and ask questions

- Students making presentations on social issues
- Doing homework or group work

- Attending classes in soft skills

- University organised scientific club

- Students attending seminars

Employers as well as alumni were very concerned about graduates' critical thinking, initiative and planning skills because these competences helped them to adapt to strange new contexts, acquire new knowledge and skills, and apply theory in practice. Alumni and lecturers agreed that these competences were mainly developed through extra-curricular activities, and non-traditional teaching and learning approaches.

\section{Discussion}

In general, employers, students and alumni of VNU and of the TuningSE project rated the importance of all GCs more highly than graduates' achievement of them. For both projects, GC3 (ability to uphold professional, moral and ethical values) was the most important competence and GC13 (ability to apply knowledge in practice) was the second, while GC7 (ability to understand, value, and respect diversity and multiculturalism) and GC11 (ability to conduct research) were considered the two least important competences.

For both projects, employers, students and alumni of VNU and of the Tuning-SE project thought graduate achievement was highest for GC3 (ability to uphold professional, moral and ethical values). Alumni and students rated graduate achievement of GC11 (ability to conduct research) at the lowest level. According to the rating of employers, VNU graduates' achievement of GC5 (ability to communicate clearly and effectively), GC6 (ability to think critically, reflectively and innovatively), GC9 (demonstrate problem-solving abilities), GC10 (ability to initiate, plan, organise, implement and evaluate courses of action), and GC13 (ability to apply knowledge in practice) was lower than for TASE graduates. The largest gap was for GC13, GC6 and GC10. 
Also in the rating of employers, VNU graduate achievement of GC1 (ability to work collaboratively and effectively in diverse contexts), GC2 (ability to use information and communication technology purposefully and responsibly), GC3 (ability to uphold professional, moral and ethical values), GC7 (ability to understand, value, and respect diversity and multiculturalism), GC8 (ability to carry out lifelong learning and continual professional development), GC11 (ability to conduct research), and GC12 (ability to demonstrate leadership attributes) was higher than for TASE graduates. The largest gap was for GC2 and GC12.

Specifically, employers of VNU graduates believed the latter's lifelong learning competence was good. VNU graduates' achievement of GC8 (ability to carry out lifelong learning and continual professional development) was rated second, though it only rated seventh in importance. However, although competence in communication, problem solving, and critical thinking is important, it rated low in achievement. VNU graduate achievement of GC5 (ability to communicate clearly and effectively) was ranked eighth by employers, and GC9 (demonstrate problem solving abilities) sixth.

Competence in critical thinking ranked last and lowest in achievement. VNU graduates' achievement of GC6 (ability to think critically, reflectively and innovatively) was rated twelfth by employers. It is worth noting that GC10 (ability to initiate, plan, organise, implement and evaluate courses of action) and GC11 (ability to conduct research) were not considered to be of great importance in employers' evaluation, nor did achievement in this area rate highly.

Like the employers, both VNU and TASE students rated the importance of general competences more highly than their achievement of them. VNU students rated all GCs at a lower level of importance than Tuning-SE Project ${ }^{51}$ students did. The widest gap was for GC7, followed by GC6, GC8, GC4, GC10, and GC2. Both VNU and Tuning-SE project students thought that GC3 (ability to uphold professional, moral and ethical values) was their best competence, and that GC11 (ability to conduct research) was lowest in their achievement. Moreover, employers thought GC11 was less important than the students did.

Students thought they were fairly good at applying knowledge in practice, and this was the most important competence in their evaluation. VNU students rated GC13 (ability to apply knowledge in practice) as fourth highest in their achievement, while Tuning-SE project students rated it second. They all thought that GC13 was the most important competence.

51 Tuning Academy, “Tuning Asia - South East, Second Meeting Report,” 22. 
In summary, VNU student ratings of their achievement of all $11 \mathrm{GCs}$ (GC7, GC13, GC2, GC1, GC8, GC9, GC5, GC6, GC10, GC12, GC11) were lower than those of Tuning-SE project students. The widest gap was for GC6 (ability to think critically, reflectively and innovatively), followed by GC10 (ability to initiate, plan, organise, implement and evaluate course of actions).

Like the employers and students, VNU alumni rated the importance of all GCs more highly than their achievement of them. VNU alumni rated 12 GCs at a lower level of importance than did alumni in the Tuning-SE project for all competences, except for GC5 (ability to communicate clearly and effectively). The widest gaps were for GC4 (ability to demonstrate responsibility and accountability towards society and environment), GC7 (ability to understand, value, and respect diversity and multiculturalism), GC10 (ability to initiate, plan, organise, implement and evaluate courses of action), and GC11 (ability to conduct research). Both groups of alumni rated GC13 (ability to apply knowledge in practice) as of greatest importance, a rating similar to that of the students.

The findings of the current research were similar to those of the Higher Education and Graduate Employment in Europe research project, ${ }^{52}$ which indicated that in the focused cognitive domains of their majors, graduates felt better prepared for their job than the job actually required. However, graduates' socio-communicative skills, values and orientations did not meet the requirements of the world of work. ${ }^{53}$ New graduates were not adequately prepared even for entry-level positions. ${ }^{54}$

We found little evidence to substantiate the view that there is a gap between employers' expectations and VNU graduates' evaluation of their achievement of the 13 general competences. Both employers and VNU alumni held a similar evaluation of graduate achievement of those competences. There was no significant difference in the mean values of the importance and achievement of the general competences in the evaluations of the employer and alumni groups.

However, we found positive evidence that the evaluations of current students about their achievement of 10 out of 13 general competences (all except for GC3, GC4, GC7) were significantly lower than employers' judgment of graduate achievement of the same competences. This result is similar to the findings of Lowden, Hall, Elliot, and Lewin, that students' broader skills and attributes, including team-working, communication,

${ }_{52}$ Schomburg and Teichler, Higher Education, 99.

${ }^{53}$ Schomburg and Teichler, ibid.

${ }^{54}$ Mourshed, Farrell, and Barton, Education to Employment, 18. 
leadership, critical thinking and problem solving, should receive greater attention..$^{55}$

An ability to apply knowledge in practice enables graduates to make use of, or apply, disciplinary knowledge. This includes linked personal attributes, cognitive abilities and skills of application. Barrie states that these generic attributes transcend disciplinary boundaries, even if they were initially developed within disciplinary contexts. Once developed, they provide a reusable framework that enables students/graduates to acquire and shape new knowledge as required - even in the context of other disciplines. ${ }^{56}$

\section{Conclusion}

The research findings demonstrate that employers, alumni, and students evaluated the importance of 13 general competences more highly than graduate achievement of them. Employers of VNU graduates gave the highest priority to such competences as the ability to communicate clearly and effectively, demonstrate problem-solving abilities, and the ability to apply knowledge in practice. VNU graduates were also rated worse than their peers in the TASE project in their ability to think critically, reflectively and innovatively, and in their ability to initiate, plan, organise, implement and evaluate courses of action. These include transferable skills, such as interactive attributes, communication skills, interpersonal skills and team working; personal attributes, such as intellect and problem solving, analytic, critical and reflective ability, willingness to learn and continue learning, flexibility, adaptability, and risk-taking; and self-management skills that are essential for graduates to enter the workplace effectively.$^{57}$ The curriculum should focus on developing general competences during the first semesters, so that students can apply these abilities to acquire important knowledge and skills more effectively.

VNU graduates rated best for their ability to uphold professional, moral and ethical values but worst for the ability to initiate, plan, organise, implement and evaluate courses of action. In this context, it might be worth taking into account alumni comments that extra-curricular activities help

${ }^{55}$ Kevin Lowden, Stuart Hall, Dely Elliot, and Jon Lewin, Employers' Perceptions of the Employability Skills of New Graduates (London: Edge Foundation, 2011), 24.

56 Barrie," Understanding," 229-30.

${ }^{57}$ Harvey, Moon, Geall, and Bower, Graduates' Work, 43. 
them become creative; develop problem-solving skills, teamwork, and communication skills.

The research also raises the concern that the students evaluated their achievement of most general competences as relatively low. Most of these students were in their second or third years of a four-year degree programme. It would be necessary for future research to investigate what activities could develop these general competences during the final terms, when major subjects focused solely on advancing disciplinary knowledge and skills.

The implication from the research findings is that the curriculum should integrate general competence training throughout the whole process, in every subject and activity - in and out of class. In particular, the focus should be placed on developing these general competences during the first semesters to support learners' acquisition of new knowledge and skills during their university study.

The findings of the current research also show the benefits of the interview technique in exploring the perspectives of employers, who were rich in information but lacked the time to participate in the survey questionnaire. Interviews can add valuable insight to the information gained from short answers or multiple choices in the survey questionnaire. Future research with a similar purpose should consider a good balance between qualitative and quantitative methods.

\section{Bibliography}

Barrie, Simon Christopher. "Academics' Understandings of Generic Graduate Attributes: A Conceptual Basis for Lifelong Learning." In Graduate Attributes, Learning and Employability. Lifelong Learning, edited by Paul Hager and Susan Holland, Book Series, v. 6, 149-167. Dordrecht: Springer, 2006. https://doi. org/10.1007/1-4020-5342-8_8.

- "Understanding what we mean by the generic attributes of graduates." Higher Education 51, no. 2 (2006): 215-41 . https://doi.org/10.1007/s10734-0046384-7.

Beneitone, Pablo, and Edurne Bartolomé. "Global Generic Competences with Local Ownership: A Comparative Study from the Perspective of Graduates in Four World Regions." Tuning Journal for Higher Education 1, no. 2 (2014): 303-334. Bennett, Roger. "Employers' Demands for Personal Transferable Skills in Graduates:

A Content Analysis of 1000 Job Advertisements and an Associated Empirical Study." Journal of Vocational Education and Training 54, no. 4 (2002): 457-76. https://doi.org/10.1080/13636820200200209.

Bennett, Neville, Elisabeth Dunne, and Clive Carré. Skills Development in Higher Education and Employment. Florence: Taylor \& Francis, Inc., 2000. 
Bodewig, Christian, and Reena Badiani-Magnusson. Skilling up Vietnam: Preparing the Workforce for a Modern Market Economy. World Bank, 2014. Accessed May 5, 2019. https://openknowledge.worldbank.org/bitstream/handle/10986/18 778/888950PUB0Box301so0829400June172014.pdf? sequence=1.

Crosling, Glenda, and Ian Ward. "Oral Communication: The Workplace Needs and Uses of Business Graduate Employees.” English for Specific Purposes 21, no. 1 (2002): 41-57.

Davies, Howard. "Competence-based Curricula in the Context of Bologna and EU Higher Education Policy." Pharmacy 5, no. 2 (2017), 17: 64-75. https://doi. org/10.3390/pharmacy5020029.

ECTS Users' Guide. Publications Office of the European Union: Luxembourg, 2015. Accessed May 13, 2019. http://ec.europa.eu/dgs/education_culture/repository/ education/library/publications/2015/ ects-users-guide_en.pdf.

Eraut, Michael. "Transfer of Knowledge between Education and Workplace Settings." In Workplace Learning in Context, edited by Helen Rainbird, Alison Fuller and Anne Munro, 201-221. London: Routledge, 2004.

European Parliament and European Council. "Recommendation of the European Parliament and of the Council of 23 April 2008 on the Establishment of the European Qualifications Framework for Lifelong Learning." Official Journal of the European Union 51, no. C 111 (2008): 1-7. http://eur-lex.europa.eu/legalcontent/EN/TXT/ PDF/?uri=CELEX:32008H0506(01)\&from=EN.

Fallows, Stephen, and Christine Steven. "The Skills Agenda." In Integrating Key Skills in Higher Education: Employability, Transferable Skills and Learning for Life, edited by Stephen Fallows and Christine Steven, 3-12. London: Kogan Page, 2000.

Haigh, Martin J., and Marianne P. Kilmartin. "Student perceptions of the development of personal transferable skills." Journal of Geography in Higher Education 23, no.2 (1999): 195-206. https://doi.org/10.1080/03098269985461.

Harvey, Lee, Sue Moon, Vicki Geall, and Ray Bower. Graduates' Work: Organisational Change and Students' Attributes. Birmingham: Centre for Research into Quality, 1997. https://doi.org/10.1177/095042229701100504.

Hernández-March, Julio, Mónica Martín Del Peso, and Santiago Leguey. “Graduates' Skills and Higher Education: The Employers' Perspective.” Tertiary Education and Management 15, no. 1 (2009): 1-16. http://dx.doi. org/10.1080/13583880802699978.

Knight, Peter T., and Mantz Yorke. "Employability through the Curriculum." Tertiary Education and Management 8, no. 4 (2002): 261-76. https://doi. org/10.1023/A:1021222629067.

Lowden, Kevin, Stuart Hall, Dely Elliot, and Jon Lewin. Employers' Perceptions of the Employability Skills of New Graduates. London: Edge Foundation, 2011.

Maclean, Rupert, and Victor Ordonez. "Work, Skills Development for Employability and Education for Sustainable Development." Educational Research for Policy and Practice 6, no. 2 (2007): 123-40. https://doi.org/10.1007/s10671-0079017-y. 
Mourshed, Mona, Diana Farrell, and Dominic Barton. Education to Employment: Designing a System that Works. McKinsey Center for Government, 2012. Accessed October 17, 2019. https://www.compromisorse.com/upload/ estudios/000/222/Education-to-Employment_FINAL.pdf.

Sánchez, Aurelio Villa and Manuel Poblete Ruiz, eds. Competence-based Learning: A Proposal for the Assessment of Generic Competences. University of Deusto, 2008. http://tuningacademy .org/wp-content/uploads/2014/02/CompetenceBased-Learning_EN.pdf.

Schomburg, Harald, and Ulrich Teichler. Higher Education and Graduate Employment in Europe, 2007. https://www.springer.com/la/ book/9781402051531.

Stephenson, John. "The Concept of Capability and Its Importance in Higher Education," In Capability and Quality in Higher Education, edited by John Stephenson and Mantz Yorke, 1-13. London: Kogan Page, 1998.

Suleman, Fátima. "Employability Skills of Higher Education Graduates: Little Consensus on a Much-discussed Subject." Procedia-Social and Behavioral Sciences 228 (2016): 169-74. https://doi.org/10.1016/j.sbspro.2016.07.025.

Trung, Tran Quang, and Fredric William Swierczek. "Skills Development in Higher Education in Vietnam." Asia Pacific Business Review 15, no. 4 (2009): 565-86. https://doi.org/10.1080/13602380802364175.

Tuning Academy. “Tuning Asia - South East, Second Meeting Report.” Unpublished document, Tuning Academy, University of Deusto, 2017. http://tuningasiasoutheast.org/second-meeting/.

Tuning Education Structures in Europe. Accessed October 17, 2019. https:// slideplayer.com/slide/1578662/.

World Bank. Vietnam - Higher Education and Skills for Growth. Washington, DC: World Bank, 2008. Accessed October 17, 2019. http://siteresources.worldbank. org/INTEASTASIAPACIFIC/Resources/Vietnam-HEandSkillsforGrowth.pdf.

Yorke, Mantz, and Lee Harvey. "Graduate Attributes and their Development." New Directions for Institutional Research 2005, no. 128 (2005): 41-58. https://doi. org/10.1002/ir.162. 


\section{Annexes}

\section{A) Annex 1}

Employers rating

\begin{tabular}{|c|c|c|c|c|}
\hline & $\begin{array}{l}\text { VNU } \\
\text { Employers }\end{array}$ & $\begin{array}{l}\text { VNU } \\
\text { Employers }\end{array}$ & $\begin{array}{l}\text { TASE project } \\
\text { Employers }\end{array}$ & $\begin{array}{l}\text { TASE project } \\
\text { Employers }\end{array}$ \\
\hline Description & Importance & Achievement & Importance & Achievement \\
\hline $\begin{array}{l}\text { GC3 Ability to uphold professional, } \\
\text { moral and ethical values }\end{array}$ & 3.69 & 3.27 & 3.7812 & 3.1805 \\
\hline $\begin{array}{l}\text { GC13 Ability to apply knowledge in } \\
\text { practice }\end{array}$ & 3.66 & 3.01 & 3.7510 & 3.1332 \\
\hline $\begin{array}{l}\text { GC5 Ability to communicate clearly } \\
\text { and effectively }\end{array}$ & 3.61 & 2.99 & 3.6628 & 3.0401 \\
\hline $\begin{array}{l}\text { GC9 Demonstrate problem-solving } \\
\text { abilities }\end{array}$ & 3.60 & 3.00 & 3.6422 & 3.0462 \\
\hline $\begin{array}{l}\text { GC6 Ability to think critically, } \\
\text { reflectively and innovatively }\end{array}$ & 3.54 & 2.88 & 3.6712 & 2.9791 \\
\hline $\begin{array}{l}\text { GC2 Ability to use information } \\
\text { and communication technology } \\
\text { purposefully and responsibly }\end{array}$ & 3.53 & 3.07 & 3.5292 & 2.9584 \\
\hline $\begin{array}{l}\text { GC8 Ability to carry out lifelong } \\
\text { learning and continual professional } \\
\text { development }\end{array}$ & 3.52 & 3.10 & 3.6806 & 3.0439 \\
\hline $\begin{array}{l}\text { GC1 Ability to work collabouratively } \\
\text { and effectively in diverse contexts }\end{array}$ & 3.46 & 3.06 & 3.6739 & 3.0218 \\
\hline $\begin{array}{l}\text { GC12 Ability to demonstrate } \\
\text { leadership attributes }\end{array}$ & 3.39 & 2.95 & 3.4362 & 2.8394 \\
\hline $\begin{array}{l}\text { GC4 Ability to demonstrate } \\
\text { responsibility and accountability } \\
\text { towards society and environment }\end{array}$ & 3.33 & 2.99 & 3.6119 & 2.9871 \\
\hline $\begin{array}{l}\text { GC10 Ability to initiate, plan, } \\
\text { organise, implement and evaluate } \\
\text { courses of action }\end{array}$ & 3.31 & 2.84 & 3.5960 & 2.9339 \\
\hline GC11 Ability to conduct research & 3.19 & 2.91 & 3.3185 & 2.8367 \\
\hline $\begin{array}{l}\text { GC7 Ability to understand, } \\
\text { value, and respect diversity and } \\
\text { multiculturalism }\end{array}$ & 3.19 & 2.99 & 3.4246 & 2.9270 \\
\hline
\end{tabular}


B) Annex 2

Student ratings

\begin{tabular}{|l|c|c|c|c|}
\hline & $\begin{array}{c}\text { VNU } \\
\text { Students }\end{array}$ & VNU Students & $\begin{array}{c}\text { TASE project } \\
\text { Students }\end{array}$ & $\begin{array}{c}\text { TASE project } \\
\text { Students }\end{array}$ \\
\hline Importance & Achievement & Importance & Achievement \\
\hline $\begin{array}{l}\text { GC13 Ability to apply knowledge in } \\
\text { practice }\end{array}$ & 3.65 & 2.83 & 3.7282 & 3.0949 \\
\hline $\begin{array}{l}\text { GC5 Ability to communicate clearly } \\
\text { and effectively }\end{array}$ & 3.59 & 2.73 & 3.5934 & 3.0245 \\
\hline $\begin{array}{l}\text { GC3 Ability to uphold professional, } \\
\text { moral and ethical values }\end{array}$ & 3.56 & 3.27 & 3.6641 & 3.1688 \\
\hline $\begin{array}{l}\text { GC9 Demonstrate problem-solving } \\
\text { abilities }\end{array}$ & 3.54 & 2.74 & 3.5940 & 3.0330 \\
\hline $\begin{array}{l}\text { GC1 Ability to work collaboratively } \\
\text { and effectively in diverse contexts }\end{array}$ & 3.47 & 2.8 & 3.5547 & 2.9811 \\
\hline $\begin{array}{l}\text { GC6 Ability to think critically, } \\
\text { reflectively and innovatively }\end{array}$ & 3.45 & 2.57 & 3.6101 & 3.0233 \\
\hline $\begin{array}{l}\text { GC8 Ability to carry out lifelong } \\
\text { learning and continual professional } \\
\text { development }\end{array}$ & 3.42 & 2.77 & 3.5802 & 3.0298 \\
\hline $\begin{array}{l}\text { GC2 Ability to use information } \\
\text { and communication technology } \\
\text { purposefully and responsibly }\end{array}$ & 3.39 & 2.8 & 3.4971 & 2.9350 \\
\hline $\begin{array}{l}\text { GC4 Ability to demonstrate } \\
\text { responsibility and accountability } \\
\text { towards society and environment }\end{array}$ & 3.37 & 3.04 & 3.5084 & 2.9697 \\
\hline $\begin{array}{l}\text { GC10 Ability to initiate, plan, } \\
\text { organise, implement and evaluate } \\
\text { courses of action }\end{array}$ & 3.33 & 2.54 & 3.4741 & 2.9355 \\
\hline $\begin{array}{l}\text { GC12 Ability to demonstrate } \\
\text { leadership attributes }\end{array}$ & 3.31 & 2.53 & 3.3746 & 2.8469 \\
\hline GC11 Ability to conduct research & 3.28 & 2.5 & 3.2884 & 2.8260 \\
\hline $\begin{array}{l}\text { GC7 Ability to understand, } \\
\text { value, and respect diversity and } \\
\text { multiculturalism }\end{array}$ & 3.24 & 2.94 & 3.4517 & 2.9854 \\
\hline & & & & \\
\hline
\end{tabular}




\section{C) Annex 3}

Alumni ratings

\begin{tabular}{|c|c|c|c|c|}
\hline & $\begin{array}{l}\text { VNU } \\
\text { Alumni }\end{array}$ & VNU Alumni & $\begin{array}{l}\text { TASE project } \\
\text { Alumni }\end{array}$ & $\begin{array}{l}\text { TASE project } \\
\text { Alumni }\end{array}$ \\
\hline & Importance & Achievement & Importance & Achievement \\
\hline $\begin{array}{l}\text { GC5 Ability to communicate clearly } \\
\text { and effectively }\end{array}$ & 3.64 & 3.15 & 3.6149 & 3.1412 \\
\hline $\begin{array}{l}\text { GC13 Ability to apply knowledge in } \\
\text { practice }\end{array}$ & 3.64 & 2.99 & 3.6328 & 3.1669 \\
\hline $\begin{array}{l}\text { GC3 Ability to uphold professional, } \\
\text { moral and ethical values }\end{array}$ & 3.62 & 3.42 & 3.6647 & 3.2606 \\
\hline $\begin{array}{l}\text { GC9 Demonstrate problem-solving } \\
\text { abilities }\end{array}$ & 3.59 & 3.04 & 3.5971 & 3.1204 \\
\hline $\begin{array}{l}\text { GC8 Ability to carry out lifelong } \\
\text { learning and continual professional } \\
\text { development }\end{array}$ & 3.52 & 3.07 & 3.6042 & 3.1744 \\
\hline $\begin{array}{l}\text { GC2 Ability to use information } \\
\text { and communication technology } \\
\text { purposefully and responsibly }\end{array}$ & 3.46 & 3.07 & 3.4798 & 3.0201 \\
\hline $\begin{array}{l}\text { GC1 Ability to work collaboratively } \\
\text { and effectively in diverse contexts }\end{array}$ & 3.46 & 3.11 & 3.5742 & 3.0951 \\
\hline $\begin{array}{l}\text { GC6 Ability to think critically, } \\
\text { reflectively and innovatively }\end{array}$ & 3.45 & 3.00 & 3.5658 & 3.1185 \\
\hline $\begin{array}{l}\text { GC4 Ability to demonstrate } \\
\text { responsibility and accountability } \\
\text { towards society and environment }\end{array}$ & 3.30 & 3.07 & 3.5361 & 3.0688 \\
\hline $\begin{array}{l}\text { GC12 Ability to demonstrate } \\
\text { leadership attributes }\end{array}$ & 3.23 & 2.90 & 3.3683 & 2.9476 \\
\hline $\begin{array}{l}\text { GC10 Ability to initiate, plan, } \\
\text { organise, implement and evaluate } \\
\text { courses of action }\end{array}$ & 3.23 & 2.88 & 3.4887 & 3.0786 \\
\hline $\begin{array}{l}\text { GC7 Ability to understand, } \\
\text { value, and respect diversity and } \\
\text { multiculturalism }\end{array}$ & 3.17 & 3.09 & 3.3901 & 3.0311 \\
\hline GC11 Ability to conduct research & 3.07 & 2.75 & 3.2599 & 2.9510 \\
\hline
\end{tabular}




\section{D) Annex 4}

VNU Employers' rankings of the priority of general competences (Weight of ranking: 1 st priority $=5$ points; 2 nd priority $=4$ points; 3rd priority $=3$ points; 4 th priority $=2$ points; 5 th priority $=1$ point)

\begin{tabular}{|c|c|c|c|c|c|c|c|}
\hline \multicolumn{7}{|c|}{ Employer ranking of the priority of general competences (number of votes) } & \multirow[b]{2}{*}{ Standardised } \\
\hline & $N=168$ & $\begin{array}{c}1 \mathrm{st} \\
\text { priority }\end{array}$ & $\begin{array}{l}\text { 2nd } \\
\text { priority }\end{array}$ & $\begin{array}{l}\text { 3rd } \\
\text { priority }\end{array}$ & $\begin{array}{l}\text { 4th } \\
\text { priority }\end{array}$ & $\begin{array}{l}5 \text { th } \\
\text { priority }\end{array}$ & \\
\hline & & (1) & (2) & (3) & (4) & (5) & $\begin{array}{l}(1 * 5+2 * 4+3 * 3+ \\
\quad 4 * 2+5 * 1)\end{array}$ \\
\hline 1 & $\begin{array}{l}\text { Ability to work collaboratively } \\
\text { and effectively in diverse } \\
\text { contexts }\end{array}$ & 25 & 17 & 9 & 8 & 12 & $\left(3^{\text {rd }}\right) 248$ \\
\hline 2 & $\begin{array}{l}\text { Ability to use information and } \\
\text { communication technology } \\
\text { purposefully and responsibly }\end{array}$ & 9 & 10 & 9 & 23 & 13 & (7th) 171 \\
\hline 3 & $\begin{array}{l}\text { Ability to uphold professional, } \\
\text { moral and ethical values }\end{array}$ & 19 & 16 & 11 & 14 & 9 & $\left(5^{\text {th }}\right) 229$ \\
\hline 4 & $\begin{array}{l}\text { Ability to demonstrate } \\
\text { responsibility and } \\
\text { accountability towards society } \\
\text { and environment }\end{array}$ & 3 & 3 & 3 & 7 & 9 & $\left(12^{\text {th }}\right) 59$ \\
\hline 5 & $\begin{array}{l}\text { Ability to communicate clearly } \\
\text { and effectively }\end{array}$ & 12 & 27 & 19 & 16 & 10 & $\left(2^{\text {nd }}\right) 267$ \\
\hline 6 & $\begin{array}{l}\text { Ability to think critically, } \\
\text { reflectively and innovatively }\end{array}$ & 10 & 7 & 14 & 12 & 13 & $\left(9^{\text {th }}\right) 157$ \\
\hline 7 & $\begin{array}{l}\text { Ability to understand, value, } \\
\text { and respect diversity and } \\
\text { multiculturalism }\end{array}$ & 1 & 0 & 3 & 2 & 3 & $\left(13^{\text {th }}\right) 21$ \\
\hline 8 & $\begin{array}{l}\text { Ability to carry out lifelong } \\
\text { learning and continual } \\
\text { professional development }\end{array}$ & 16 & 14 & 19 & 6 & 11 & $\left(6^{\text {th }}\right) 216$ \\
\hline 9 & $\begin{array}{l}\text { Demonstrate problem solving } \\
\text { abilities }\end{array}$ & 17 & 14 & 18 & 19 & 12 & $\left(4^{\text {th }}\right) 245$ \\
\hline 10 & $\begin{array}{l}\text { Ability to initiate, plan, } \\
\text { organise, implement and } \\
\text { evaluate courses of action }\end{array}$ & 5 & 7 & 14 & 4 & 6 & $\left(11^{\text {th }}\right) 109$ \\
\hline 11 & Ability to conduct research & 6 & 16 & 6 & 9 & 6 & $\left(10^{\text {th }}\right) 136$ \\
\hline 12 & $\begin{array}{l}\text { Ability to demonstrate } \\
\text { leadership attributes }\end{array}$ & 6 & 10 & 15 & 17 & 21 & $\left(8^{\text {th }}\right) 170$ \\
\hline 13 & $\begin{array}{l}\text { Ability to apply knowledge in } \\
\text { practice }\end{array}$ & 26 & 14 & 13 & 16 & 27 & $\left(1^{\text {st }}\right) 284$ \\
\hline
\end{tabular}




\section{E) Annex 5}

VNU student rankings of the priority of general competences

\begin{tabular}{|c|c|c|c|c|c|c|c|}
\hline \multicolumn{7}{|c|}{ Student rankings of the priority of general competences (number of votes) } & \multirow[b]{2}{*}{ Standardised } \\
\hline \multicolumn{2}{|r|}{$N=258$} & $\begin{array}{c}1 s t \\
\text { priority }\end{array}$ & $\begin{array}{l}\text { 2nd } \\
\text { priority }\end{array}$ & $\begin{array}{c}\text { 3rd } \\
\text { priority }\end{array}$ & $\begin{array}{l}\text { 4th } \\
\text { priority }\end{array}$ & $\begin{array}{l}5 \text { th } \\
\text { priority }\end{array}$ & \\
\hline & & (1) & (2) & (3) & (4) & (5) & $\begin{array}{c}(1 * 5+2 * 4+3 * 3+ \\
4 * 2+5 * 1)\end{array}$ \\
\hline 1 & $\begin{array}{l}\text { Ability to work collaboratively } \\
\text { and effectively in diverse } \\
\text { contexts }\end{array}$ & 38 & 10 & 15 & 17 & 18 & $\left(5^{\text {th }}\right) 327$ \\
\hline 2 & $\begin{array}{l}\text { Ability to use information and } \\
\text { communication technology } \\
\text { purposefully and responsibly }\end{array}$ & 10 & 22 & 6 & 12 & 22 & $\left(8^{\text {th }}\right) 202$ \\
\hline 3 & $\begin{array}{l}\text { Ability to uphold professional, } \\
\text { moral and ethical values }\end{array}$ & 22 & 15 & 21 & 12 & 20 & $\left(6^{\text {th }}\right) 277$ \\
\hline 4 & $\begin{array}{l}\text { Ability to demonstrate } \\
\text { responsibility and } \\
\text { accountability towards society } \\
\text { and environment }\end{array}$ & 2 & 6 & 9 & 13 & 14 & $\left(12^{\text {th }}\right) 101$ \\
\hline 5 & $\begin{array}{l}\text { Ability to communicate clearly } \\
\text { and effectively }\end{array}$ & 35 & 43 & 32 & 24 & 33 & $\left(1^{\text {st }}\right) 524$ \\
\hline 6 & $\begin{array}{l}\text { Ability to think critically, } \\
\text { reflectively and innovatively }\end{array}$ & 17 & 34 & 29 & 27 & 15 & $\left(4^{\text {th }}\right) 377$ \\
\hline 7 & $\begin{array}{l}\text { Ability to understand, value, } \\
\text { and respect diversity and } \\
\text { multiculturalism }\end{array}$ & 1 & 6 & 16 & 8 & 5 & $\left(13^{\text {th }}\right) 98$ \\
\hline 8 & $\begin{array}{l}\text { Ability to carry out lifelong } \\
\text { learning and continual } \\
\text { professional development }\end{array}$ & 20 & 20 & 16 & 12 & 7 & $\left(7^{\text {th }}\right) 259$ \\
\hline 9 & $\begin{array}{l}\text { Demonstrate problem-solving } \\
\text { abilities }\end{array}$ & 18 & 32 & 36 & 36 & 17 & $\left(3^{\text {nd }}\right) 415$ \\
\hline 10 & $\begin{array}{l}\text { Ability to initiate, plan, } \\
\text { organise, implement and } \\
\text { evaluate courses of action }\end{array}$ & 8 & 8 & 18 & 22 & 14 & $\left(9^{\text {th }}\right) 184$ \\
\hline 11 & Ability to conduct research & 15 & 6 & 6 & 10 & 11 & $\left(11^{\text {th }}\right) 148$ \\
\hline 12 & $\begin{array}{l}\text { Ability to demonstrate } \\
\text { leadership attributes }\end{array}$ & 13 & 7 & 6 & 16 & 15 & (10th) 158 \\
\hline 13 & $\begin{array}{l}\text { Ability to apply knowledge in } \\
\text { practice }\end{array}$ & 35 & 25 & 24 & 24 & 42 & (2nd) 437 \\
\hline
\end{tabular}




\section{F) Annex 6}

VNU alumni rankings of the priority of general competences

\begin{tabular}{|c|c|c|c|c|c|c|c|}
\hline \multicolumn{7}{|c|}{ Ranking the priority of general competences by the alumni (number of votes) } & \multirow[b]{2}{*}{ Standardised } \\
\hline & $N=152$ & $\begin{array}{c}1 \text { st } \\
\text { priority }\end{array}$ & $\begin{array}{l}\text { 2nd } \\
\text { priority }\end{array}$ & $\begin{array}{l}\text { 3rd } \\
\text { priority }\end{array}$ & $\begin{array}{l}\text { 4th } \\
\text { priority }\end{array}$ & $\begin{array}{l}5 \text { th } \\
\text { priority }\end{array}$ & \\
\hline & & (1) & $(2)$ & (3) & (4) & (5) & $\begin{array}{c}(1 * 5+2 * 4+3 * 3+ \\
4 * 2+5 * 1)\end{array}$ \\
\hline 1 & $\begin{array}{l}\text { Ability to work collaboratively } \\
\text { and effectively in diverse } \\
\text { contexts }\end{array}$ & 14 & 5 & 8 & 11 & 15 & $\left(6^{\text {th }}\right) 151$ \\
\hline 2 & $\begin{array}{l}\text { Ability to use information and } \\
\text { communication technology } \\
\text { purposefully and responsibly }\end{array}$ & 4 & 9 & 10 & 13 & 12 & $\left(8^{\text {th }}\right) 124$ \\
\hline 3 & $\begin{array}{l}\text { Ability to uphold professional, } \\
\text { moral and ethical values }\end{array}$ & 11 & 12 & 11 & 9 & 10 & $\left(4^{\text {th }}\right) 164$ \\
\hline 4 & $\begin{array}{l}\text { Ability to demonstrate } \\
\text { responsibility and } \\
\text { accountability towards society } \\
\text { and environment }\end{array}$ & 2 & 1 & 2 & 5 & 2 & $\left(12^{\text {th }}\right) 32$ \\
\hline 5 & $\begin{array}{l}\text { Ability to communicate clearly } \\
\text { and effectively }\end{array}$ & 19 & 19 & 19 & 11 & 8 & $\left(1^{\text {st }}\right) 258$ \\
\hline 6 & $\begin{array}{l}\text { Ability to think critically, } \\
\text { reflectively and innovatively }\end{array}$ & 7 & 16 & 14 & 8 & 4 & $\left(5^{\text {th }}\right) 161$ \\
\hline 7 & $\begin{array}{l}\text { Ability to understand, value, } \\
\text { and respect diversity and } \\
\text { multiculturalism }\end{array}$ & 1 & 1 & 2 & 4 & 3 & $\left(13^{\text {th }}\right) 26$ \\
\hline 8 & $\begin{array}{l}\text { Ability to carry out lifelong } \\
\text { learning and continual } \\
\text { professional development }\end{array}$ & 13 & 10 & 5 & 10 & 8 & $\left(7^{\text {th }}\right) 148$ \\
\hline 9 & $\begin{array}{l}\text { Demonstrate problem-solving } \\
\text { abilities }\end{array}$ & 13 & 14 & 14 & 17 & 13 & $\left(2^{\text {nd }}\right) 210$ \\
\hline 10 & $\begin{array}{l}\text { Ability to initiate, plan, } \\
\text { organise, implement and } \\
\text { evaluate courses of action }\end{array}$ & 4 & 6 & 8 & 5 & 7 & $\left(10^{\text {th }}\right) 85$ \\
\hline 11 & Ability to conduct research & 3 & 3 & 3 & 6 & 7 & $\left(11^{\text {th }}\right) 55$ \\
\hline 12 & $\begin{array}{l}\text { Ability to demonstrate } \\
\text { leadership attributes }\end{array}$ & 6 & 6 & 7 & 7 & 14 & $\left(9^{\text {th }}\right) 103$ \\
\hline 13 & $\begin{array}{l}\text { Ability to apply knowledge in } \\
\text { practice }\end{array}$ & 17 & 12 & 11 & 7 & 10 & $\left(3^{\text {rd }}\right) 190$ \\
\hline
\end{tabular}




\section{About the author}

DR. LAN THI QUYNH MAI (lanmtq@vnu.edu.vn) works at the Institute for Education Quality Assurance of Vietnam National University, Hanoi, as the Head of the Department for Quality Assurance Research and Management. She holds a Bachelor's degree in teaching English. She was awarded a full scholarship at the University of Queensland (the Atlantic Philanthropies scholarship) to pursue a Master's degree in Social Planning and Development (Professional), and a co-funded grant from the Vietnam Ministry of Education and the University of Queensland to complete a PhD in Sociology at the School of Sociology, University of Queensland, Australia. Since 2005, she has been working in the education quality assurance area, where her focus is graduate attributes and competences. Her professional interest is in exploring the gaps between the competences gained from university and the actual requirements of the new world of work. She is also interested in research into higher education in the $4^{\text {th }}$ Industrial Revolution era, curriculum reform, the transition from university to the workplace, graduates' work experience, the intercultural workplace, intercultural competence, cultural mediation, and cultural intermediaries. She is the author and co-author of book chapters published by Springer International Publishing AG, Cham and Routledge, and has written various articles published in international journals. 


\title{
Stakeholder perspectives on general competences: The case of graduates of Vietnam National University, Hanoi
}

\author{
Lan Thi Quynh Mai
}

doi: http://dx.doi.org/10.18543/tjhe-7(2)-2020pp91-139

\section{Copyright}

Copyright for this article is retained by the Publisher. It is an Open Access material that is free for full online access, download, storage, distribution, and or reuse in any medium only for noncommercial purposes and in compliance with any applicable copyright legislation, without prior permission from the Publisher or the author(s). In any case, proper acknowledgement of the original publication source must be made and any changes to the original work must be indicated clearly and in a manner that does not suggest the author's and or Publisher's endorsement whatsoever. Any other use of its content in any medium or format, now known or developed in the future, requires prior written permission of the copyright holder. 